OPEN ACCESS

Edited by:

Jonah Henri Ratsimbazafy,

Madagascar Primate Study

and Research Group, Madagascar

Reviewed by:

Peter Andrew Gell,

Federation University Australia,

Australia

Chris Schneider,

University of Alberta, Canada

*Correspondence:

Matthew P. Duda

mattpduda@gmail.com

Specialty section:

This article was submitted to

Conservation and Restoration

Ecology,

a section of the journal

Frontiers in Ecology and Evolution

Received: 20 April 2021

Accepted: 20 August 2021

Published: 22 September 2021

Citation:

Duda MP, Hargan KE,

Michelutti N, Blais JM, Grooms C, Gilchrist HG, Mallory ML,

Robertson GJ and Smol JP (2021)

Reconstructing Long-Term Changes

in Avian Populations Using Lake

Sediments: Opening a Window Onto

the Past. Front. Ecol. Evol. 9:698175.

doi: 10.3389/fevo.2021.698175

\section{Reconstructing Long-Term Changes in Avian Populations Using Lake Sediments: Opening a Window Onto the Past}

\author{
Matthew P. Duda ${ }^{1 *}$, Kathryn E. Hargan ${ }^{2}$, Neal Michelutti', Jules M. Blais ${ }^{3}$, \\ Christopher Grooms ${ }^{1}$, H. Grant Gilchrist ${ }^{4}$, Mark L. Mallory ${ }^{5}$, Gregory J. Robertson ${ }^{6}$ and \\ John P. Smol ${ }^{1}$

\begin{abstract}
'Paleoecological Environmental Assessment and Research Lab (PEARL), Department of Biology, Queen's University, Kingston, ON, Canada, ${ }^{2}$ Department of Biology, Memorial University of Newfoundland, St. John's, NL, Canada, ${ }^{3}$ Department of Biology, University of Ottawa, Ottawa, ON, Canada, ${ }^{4}$ Environment and Climate Change Canada, Wildlife Research Division, Ottawa, ON, Canada, ${ }^{5}$ Department of Biology, Acadia University, Wolfville, NS, Canada, ${ }^{6}$ Environment and Climate Change Canada, Wildlife Research Division, Mount Pearl, NL, Canada
\end{abstract}

The lack of long-term monitoring data for many wildlife populations is a limiting factor in establishing meaningful and achievable conservation goals. Even for wellmonitored species, time series are often very short relative to the timescales required to understand a population's baseline conditions before the contemporary period of increased human impacts. To fill in this critical information gap, techniques have been developed to use sedimentary archives to provide insights into long-term population dynamics over timescales of decades to millennia. Lake and pond sediments receiving animal inputs (e.g., feces, feathers) typically preserve a record of ecological and environmental information that reflects past changes in population size and dynamics. With a focus on bird-related studies, we review the development and use of several paleolimnological proxies to reconstruct past colony sizes, including trace metals, isotopes, lipid biomolecules, diatoms, pollen and non-pollen palynomorphs, invertebrate sub-fossils, pigments, and others. We summarize how animal-influenced sediments, cored from around the world, have been successfully used in addressing some of the most challenging questions in conservation biology, namely: How dynamic are populations on long-term timescales? How may populations respond to climate change? How have populations responded to human intrusion? Finally, we conclude with an assessment of the current state of the field, challenges to overcome, and future potential for research.

Keywords: paleolimnology, long-term, biovector, conservation, monitoring, baselines, management, birds

\section{INTRODUCTION}

Traditionally, wildlife monitoring programs require continuous and sustained investment, and are thus costly, labor-intensive, and potentially distressing for the organism (Witmer, 2005). Furthermore, although modern monitoring methods provide estimates or indices of contemporary population size, most are relatively recent in implementation and thus provide limited insights into 
population trends that naturally change over many generations and varying ecological conditions. As a result, resources are typically allocated to populations that are currently of interest or concern, and thus most management programs are responsive to population changes as opposed to predictive of population change. This unfortunate lack of long-term data is well established. For example, Bonebrake et al. (2010) demonstrated that only $15 \%$ of studies examining population declines used data that were older than 100 years and that only $42 \%$ used monitoring data collected annually. In the same vein, several reviews have reiterated the importance of long-term perspectives to effectively address various environmental issues and to formulate effective decision-making in conservation biology (Willis and Birks, 2006; Froyd and Willis, 2008; Lotze and Worm, 2009; Dietl and Flessa, 2011; Seddon et al., 2014; Dietl et al., 2015).

As with most wildlife, many bird populations around the world are in decline (e.g., Şekercioğlu et al., 2004; Inger et al., 2014; Paleczny et al., 2015; Beresford et al., 2019). Since 1970, there has been a staggering net loss of nearly three billion birds in North America (Rosenberg et al., 2019), and this estimate does not incorporate the known declines in seabird populations (Paleczny et al., 2015). Compounding this growing conservation issue is the reality that, for the majority of species, there is a lack of adequate long-term monitoring data to effectively consider baseline population size or natural variability when establishing management strategies and targets. As a result, it is very challenging to disentangle whether a species is declining as a result of anthropogenic activities and thus requires human intervention and/or whether the population is within the range of long-term natural variability and thus requires a different approach to maintain natural dynamics.

In response to the dearth of long-term monitoring data, a variety of methods have been developed to identify long-term trends in bird populations and diet, termed "paleornithology" (reviewed in Wood and De Pietri, 2015). To identify the demographic history on an evolutionary time scale (i.e., $>10,000$ years), ancient DNA (or aDNA) has been used. For example, genetic methods have been successfully employed to identify the population trends of the extinct passenger pigeon (Ectopistes migratorius) (Hung et al., 2014), the population recovery of the crested ibis (Nipponia nippon) (Feng et al., 2019), and population trends in Adélie penguins (Pygoscelis adeliae) and emperor penguins (Aptenodytes forsteri) in response to climate changes ( $\mathrm{Li}$ et al., 2014). However, aDNA is less effective for more recent population trends (i.e., $<10,000$ years) because insufficient time has elapsed for the accumulation of evidence of evolutionary change. In the critical period from the present until $\sim 10,000$ years BP (before present, where 0 is $1950 \mathrm{CE}$ ), we argue that paleolimnology, or the study of lake and pond sediments as historical archives, can be a highly effective approach to access long-term population demographics. In this review, we provide an accessible summary of current developments and future directions on how paleoecological approaches can be useful to reconstruct long-term animal trends, with a focus on avian colonies. We provide an overview of the paleolimnological approach and its methodologies, geared toward researchers who are unfamiliar with these techniques. Also, we present a variety of case studies that address critical questions that are broadly important in modern conservation biology. Ultimately, we believe that combining paleoecological techniques with modern wildlife monitoring approaches will provide new perspectives to address pressing conservation questions, help identify drivers of population declines, understand natural population dynamics, and provide a better understanding of how populations have changed in the past to establish predictions of future population trends.

\section{What Is Paleolimnology?}

Paleolimnology is the study of the physical, chemical, and biological information stored in lake and river sediments (Smol, 2008). Sediments provide archives of various indicators of environmental change within a given body of water, from the surrounding catchment, and from atmospheric deposition. As such, lake sediments can provide long-term perspectives that predate historical records, and thus can be used to help place recent monitoring data into an ecologically relevant temporal context.

The use of paleolimnology to reconstruct past population dynamics is built on the well-established role of certain animals as effective biological vectors of nutrients and other products that are capable of modifying their environment (e.g., Blais et al., 2007). These biological vectors, typically shortened to "biovectors," can have various influences on the environment, broadly classified as trophic level effects and transport effects (Bauer and Hoye, 2014). Trophic level effects occur when large groups of organisms alter the food web through changing the availability of a resource, such as desert locusts (Schistocerca gregaria) consuming and devastating crops (Sánchez-Zapata et al., 2007) or zebra mussels (Dreissena polymorpha) selectively filtering desirable algae from the water, resulting in blooms of undesirable and toxic Microcystis (Vanderploeg et al., 2001). Transport effects are changes in an ecosystem resulting from the collection, concentration, and transportation of large amounts of nutrients, plant propagules, and parasites from one location to another. For example, anadromous fishes and colonial seabirds transport and concentrate nutrients, metals, and contaminants from their aquatic feeding grounds to their terrestrial breeding territories (e.g., Evenset et al., 2007a,b; Michelutti et al., 2009; Holtgrieve and Schindler, 2011). Because of the vast influences of biovectors on the environment, many are considered "ecosystem engineers," or organisms that biotically or abiotically change the availability of resources for other species (Jones et al., 1994).

Many of the ecosystem changes linked to biovectors are preserved in nearby bodies of water and can be reconstructed to understand changes in past biovector abundance (Figure 1). Briefly, a site that receives substantial waste products (either washed or blown in or from direct inputs) to a body of water is selected. Lacustrine environments (i.e., standing water) are preferred, as the sediments tend to accumulate chronologically with minimal mixing, in contrast to those in fluvial environments (i.e., running water) (Smol, 2008). There is also a limited but growing body of literature using similar paleolimnological approaches on peat (Outridge et al., 2016; Davidson et al., 2018; Groff et al., 2020), directly from nests (Burnham et al., 2009), 
and on guano deposits themselves (Nocera et al., 2012; Gallant et al., 2020, 2021). Next, the sample is collected using a sediment corer, which, in its simplest form, is a tube inserted into the sediment to retrieve an undisturbed vertical profile of sediment [see Glew et al. (2001) for a detailed overview]. The sediment core is then sectioned into discrete intervals and dated using a variety of physical [e.g., laminated sediment layers (varves) or volcanic ash layers (tephra)] and radioisotopic (e.g., ${ }^{210} \mathrm{~Pb},{ }^{137} \mathrm{Cs}$, ${ }^{14} \mathrm{C}$ ) techniques [see Appleby (2001) and Björck and Wohlfarth (2001) for detailed overviews]. Finally, sediments are analyzed for a variety of proxies that directly (e.g., geochemistry, $\delta^{15} \mathrm{~N}$, lipid biomolecules) and indirectly (e.g., diatoms, invertebrate subfossils, pollen and non-pollen palynomorphs) track the presence and influences of the biovectors (Figure 2). Typically, multiple proxies are used for a "weight-of-evidence" approach (Smol, 2008) because increasing the number of corroborative proxies strengthens the accuracy of the reconstruction and minimizes the confounding impacts of extraneous influences.

Some of the earliest paleolimnological reconstructions of biovectors linked changes in sediment geochemistry to avian inputs to make inferences about past Adélie penguin rookery size (Zale, 1994). The technique was then expanded across the Antarctic in a series of studies aimed at understanding the long-term population changes in response to past climate (e.g., Sun et al., 2000, 2004; Huang et al., 2009a). In the Northern Hemisphere, similar reconstructions conducted on Pacific sockeye salmon (Oncorhynchus nerka) identified striking fluctuations in numbers that were correlated to climate change and other environmental stressors (Finney et al., 2000, 2002; Gregory-Eaves et al., 2003; Selbie et al., 2007). Afterward, work from Cape Vera (Devon Island, Nunavut) in the Canadian High Arctic successfully expanded the field by demonstrating the utility of a variety of proxies that could be successfully used to reconstruct seabird numbers with sediments, including contaminants, stable isotopes (e.g., $\delta^{15} \mathrm{~N}$ ), invertebrate subfossils, and lipid biomolecules (Blais et al., 2007; Evenset et al., 2007a,b; Michelutti et al., 2009, 2011; Cheng et al., 2016, 2021). Since these studies, the use of sedimentary archives in biovector work has rapidly expanded to other organisms (e.g., Navarro et al., 2017; Gallant et al., 2020) and spatially to other regions (Supplementary Table 1).

Although a variety of animal groups can be tracked using sediment archives (e.g., butterflies and moths, fish, birds, bats), the focus of this review will be on aquatic birds, a globally widespread biovector with behaviors that are conducive to paleolimnological studies. Aquatic birds, especially seabirds, are an ideal study group for population reconstructions as $95 \%$ of seabirds are colonial (Danchin and Wagner, 1997), thus forming large congregations that concentrate their waste products (Otero et al., 2018), which can be archived in lakes. Seabirds are also highly visible sentinel species of marine ecosystem functioning, and therefore changes in observed seabird numbers may provide useful information about unobserved components of the marine environment (e.g., Parsons et al., 2008; Hazen et al., 2019; Velarde et al., 2019). As a result, the well-documented, global decline in seabird numbers highlights the pressing need for information that can lead to effective conservation and management. In
Figure 2, we depict some of the key paleolimnological proxies that will be discussed in this review.

\section{PALEOLIMNOLOGICAL PROXIES USED FOR POPULATION RECONSTRUCTIONS}

\section{Bio-Elements}

One of the most useful paleolimnological proxies for reconstructing bird colony size is sedimentary elements that are primarily of biogenic origins. As seabirds typically occupy upper trophic positions of the food web, they may carry high amounts of elements as a result of the concentrating effects of bioaccumulation and biomagnification (Mallory and Braune, 2012). Importantly, the cocktail of elements and their concentrations vary depending on a variety of factors, including age, species, location of feeding grounds, and, especially, diet and trophic position (Honda et al., 1990; Lock et al., 1992; Michelutti et al., 2010b). Based on these factors, various seabird species may introduce differing combinations of elements (often termed "bio-elements") to their breeding grounds that can be used to track changes in colony size with sediment records. This technique assumes that the diet and trophic position of the tracked species remains consistent and that the elements excreted by the study species remain similar throughout the record.

Elements accumulated in a bird's body can be released to the local environment via feces, dropped or regurgitated food and stomach oils, as well as eggshells, feathers, and carcasses of deceased adults or young (Liu et al., 2006a; De La Peña-Lastra, 2021). These products then ultimately drain into a nearby body of water, where they can be tracked in dated lake sediments. As such, changes in the concentrations of trace metals linked to avian deposition can inform changes in the colony size.

Element concentrations, however, do not have a one-to-one relationship with colony size, and a variety of factors must be considered when making inferences about numbers. For example, it is important to consider natural geological sources of metals in the sediments such as the soils of the catchment, hydrology, and sedimentation conditions, as well as potential post-depositional factors that may confound interpretations (Boës et al., 2011). Therefore, normalization is often used to distinguish which portion of the measured sedimentary metal load is most likely derived from the seabirds. A twotiered approach is recommended. First, sieving is suggested to minimize the influences of grain size. Next, elements-of-interest should be normalized against a conservative lithogenic element (i.e., one that is geochemically stable and therefore changes in its concentration would reflect post-depositional processes, such as erosion) (Kersten and Smedes, 2002). Normalization simply entails dividing the element of interest by a conservative lithogenic element. Effective elements for normalization include aluminum (Al), lithium (Li), rubidium $(\mathrm{Rb})$, titanium $(\mathrm{Ti})$, and zirconium (Zr) (Loring, 1991; Boës et al., 2011), with Al and Ti the most used in paleolimnological studies (Roberts et al., 2017; Gao et al., 2018c; Duda et al., 2020a,c).

Once normalized, it is important to distinguish which elements are representative of seabird inputs and which are 


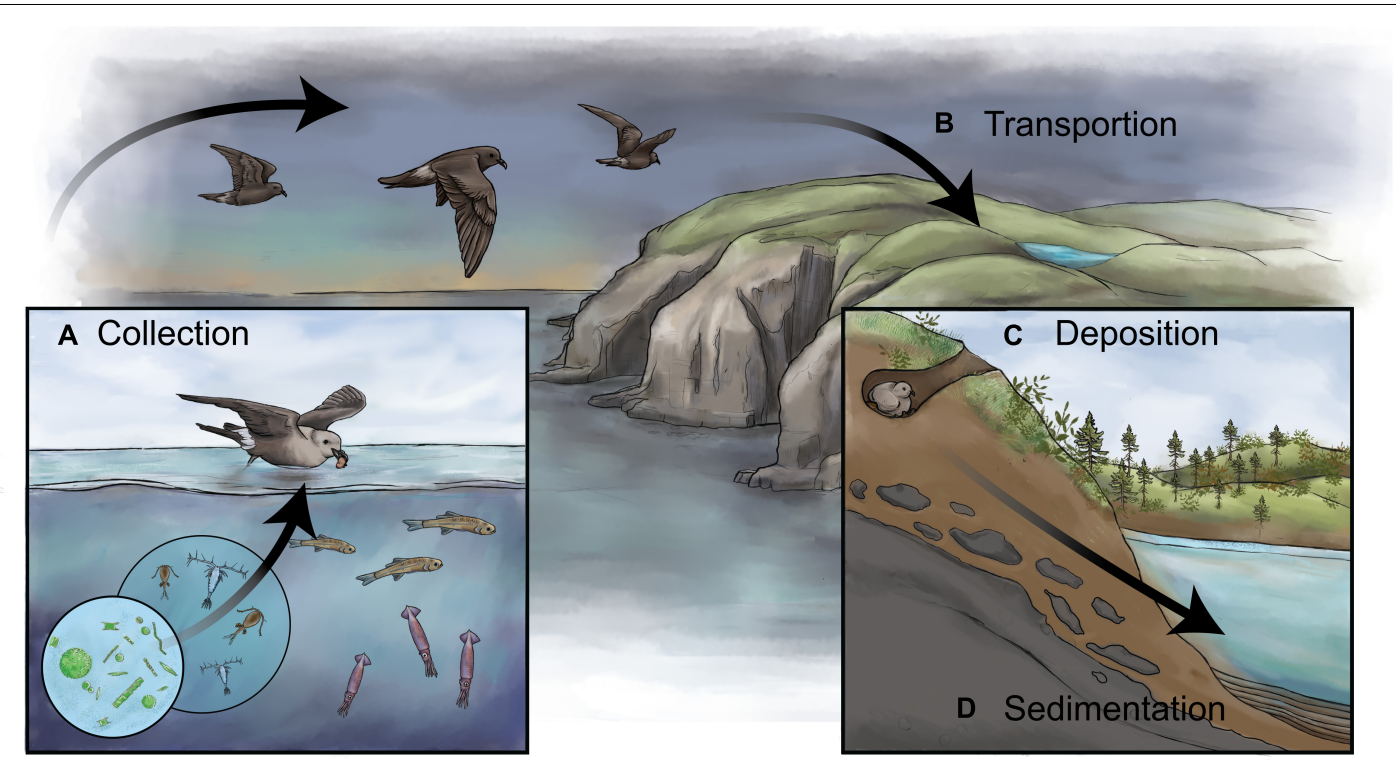

FIGURE 1 | A schematic showing how biovectors can influence inland bodies of water and how sediments can be used to reconstruct past colony dynamics. (A) Biovectors, in this case storm-petrels, typically occupy a high-trophic level and are gregarious on land. When feeding in the open ocean, they collect and concentrate marine nutrients (i.e., N, P) and other products, including stable isotopes (e.g., $\left.\delta^{15} \mathrm{~N}\right)$, bio-elements (e.g., Cd, Zn, Hg), and contaminants. (B) Biovectors transport these nutrients and other products from their feeding grounds to terrestrial breeding colonies. (C) The nutrients and other products are deposited in high concentrations onto the landscape via wastes in the forms of feces, dropped or regurgitated food, eggshells, feathers, and carcasses. (D) In the presence of a receiving body of water, such as a lake or pond, the waste products alter the water chemistry and, subsequently, the biotic assemblages, which are then archived in a waterbody's sediments, thus creating a continuous long-term record of changes in the colony size. By retrieving a dated sediment core from the biovector-influenced pond and analyzing it for paleolimnological proxies, it is possible to reconstruct changes in past colony size.

from the catchment. This can be done with R-cluster analysis (Huang et al., 2009a), biogenic enrichment factors (Brimble et al., 2009), or an index of geoaccumulation (Müller, 1979; Förstner et al., 1993). R-cluster analysis (sometimes called R mode cluster analysis") is a statistical technique used to partition and identify similar groups of elements and infer their origin. With an understanding of the elements introduced by the species of interest, it is possible to identify a group of elements of the same origin. As demonstrated in Figure 3, Liu et al. (2005) examined 24 elements from a sediment core collected in Ardley Island in the Antarctic that was influenced by a major colony of gentoo penguins (Pygoscelis papua), Adélie penguins, and chinstrap penguins (Pygoscelis antarctica). Using R-cluster analysis, followed by a Pearson correlation, the authors identified phosphorus $(\mathrm{P})$, copper $(\mathrm{Cu})$, strontium $(\mathrm{Sr})$, zinc $(\mathrm{Zn})$, selenium (Se), calcium (Ca), fluorine $(\mathrm{F})$, and sulfur $(\mathrm{S})$ as bio-elements with the same origins that were highly correlated to one another (Figure 3). By comparing this grouping to previously published chemical analyses of penguin droppings, the authors confirmed that the group of bio-elements is representative of the species of interest, and so could be used to understand changes in penguin numbers back in time. R-cluster analysis, which has been used worldwide, is often considered the most effective tool to identify ornithogenic elements if a nearby reference site (i.e., a nearby lake without avian inputs) is not available to distinguish the natural, background element concentrations (Zale, 1994; Sun et al., 2000, 2004; Liu et al., 2005, 2006c; Huang et al., 2009a, 2011; Xu et al., 2011, 2016, 2019, 2020; Roberts et al., 2017).

In situations with geochemical measurements from a reference site and a biovector fecal sample, it is possible to use biogenic enrichment factors $(B)$ to more specifically identify the elements introduced by the target species (Brimble et al., 2009). $B$ is calculated as the ratio of the concentration of an element in the feces to the concentration of the same element in the surface sediment of a reference site. Thus, any $B$ value greater than one indicates that the concentration in feces is higher than in the reference conditions, and therefore the element concentration in the sediment is likely to be of ornithogenic origin, specific to the focal species. This technique provides more specific markers of avian inputs compared to R-cluster analysis, but it is less commonly used given that fecal samples are also needed. Biogenic enrichment factors have been useful in the Canadian High Arctic to track changes in northern fulmar (Fulmarus glacialis), where Brimble et al. (2009) identified arsenic (As), cadmium $(\mathrm{Cd})$, potassium $(\mathrm{K}), \mathrm{P}$, and $\mathrm{Zn}$ as primarily fulmarderived elements. Similar approaches were used on islands in the Northwest Atlantic Ocean to link Cd and $\mathrm{Zn}$ to inputs from Leach's storm-petrel (Hydrobates leucorhous) (Duda et al., 2020a,c).

The final method to identify the bio-elements introduced by a seabird is with an index of geoaccumulation ( $I_{\text {geo }}$, sometimes "geoaccumulation index"). This method is similar to biogenic enrichment factors, although it uses bird-influenced sediments 


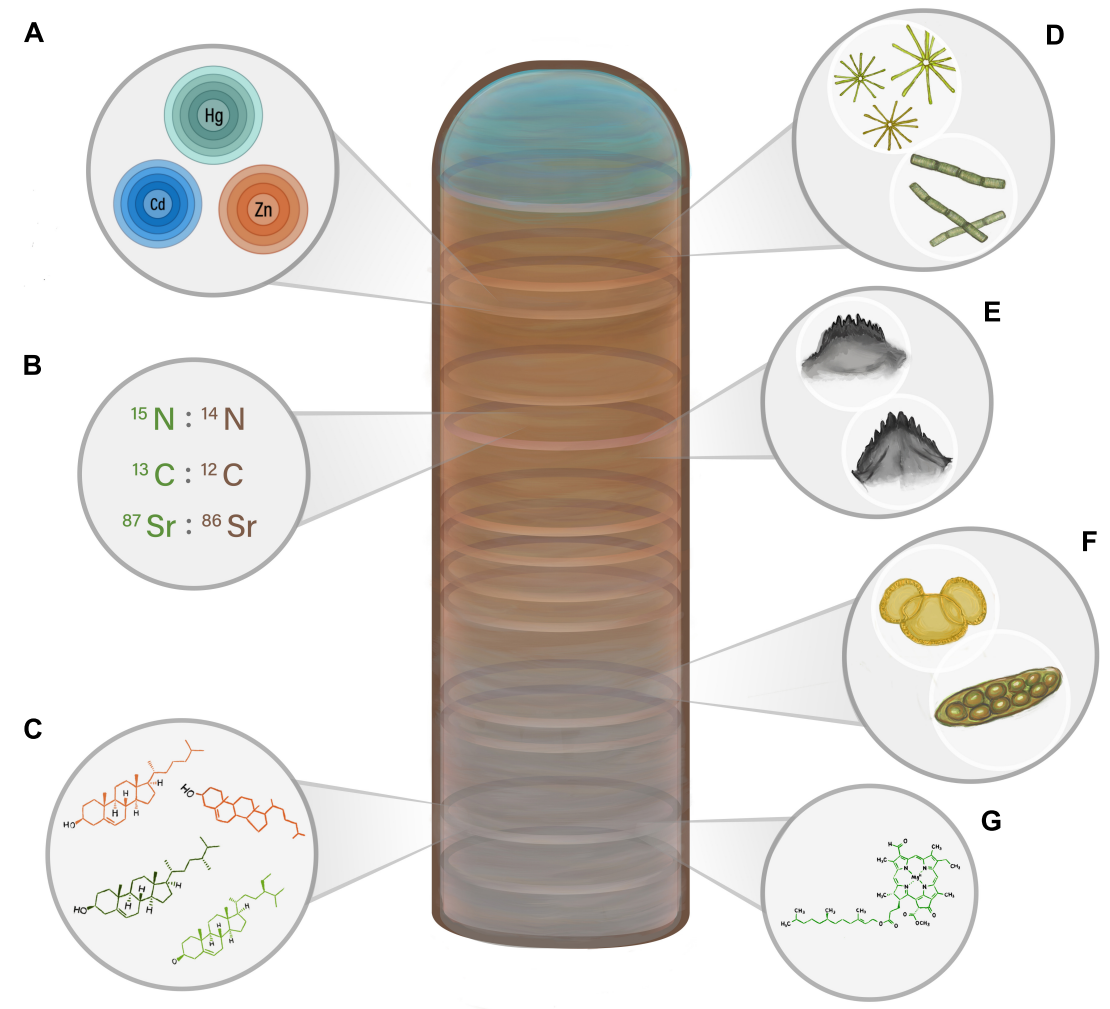

FIGURE 2 | A visual representation of the main paleolimnological proxies discussed in this review that can be used to reconstruct past biovector numbers. Increases and decreases in colony size, and thus the amount of biovector waste inputs, can result in changes in the relative abundance and prevalence of the proxies, including (A) bio-elements; (B) stable isotope ratios; (C) lipid biomolecules; (D) diatoms; (E) invertebrate sub-fossils; (F) terrestrial pollen and non-pollen palynomorphs; and (G) pigments.

instead of feces to compare with reference conditions (Müller, 1979; Förstner et al., 1993). The equation for $I_{g e o}$ for each element of interest is given as

$$
I_{g e o}=\log _{2}\left(C_{n} / 1.5 B_{n}\right)
$$

where $C_{n}$ is the element concentration in the biovector influenced sediment, $B_{n}$ is the element concentration in local bedrock, and 1.5 is a factor to correct for possible variations in lithology. The result is then compared to a table to infer the level of contamination of the element by the seabirds (Table 1). Using $I_{g e o}$, inputs from emperor penguins were linked to the enrichment of mercury ( $\mathrm{Hg}$ ), total phosphorus, $\mathrm{Zn}$, Se, and $\mathrm{Cd}$ (Huang et al., 2014, 2016).

An important consideration when selecting the elements to track changes in avian populations is the potential interactions of the element with sediment composition and limnological conditions. For example, although $\mathrm{P}$ is highly elevated in most avian guano, it is also affected by desorption and resorption reactions in sediment (Koski-Vähälä et al., 2001) and can be highly mobile in anoxic sediments (Ginn et al., 2012). These events are triggered by the release of $\mathrm{P}$ bound to iron ( $\mathrm{Fe})$ - and Al-rich sediments, which can occur during periods of elevated $\mathrm{pH}$, increased silicon, and anaerobic conditions (Koski-Vähälä et al., 2001). This $\mathrm{P}$ release, when not accounted for, can result in erroneous interpretations of the seabird colony size. Other elements, such as As and Zn, may also become labile in sediments in response to changes in $\mathrm{pH}$, salinity, temperature, organic matter, and, in particular, redox conditions (Couture et al., 2010; Wang et al., 2015; Kouassi et al., 2019). Although bio-elements can provide an effective proxy for avian inputs, it is important to always consider any potential post-depositional effects when interpreting the results.

\section{Isotope Ratios}

Stable isotope analysis has a long history of use in paleolimnological reconstructions (Leng, 2006). The use of stable isotopes is predicated on the observation that the ratio of the heavier and lighter isotopes changes based on their source. In paleolimnological studies, the most common stable isotopes investigated are nitrogen $(\mathrm{N})$ and carbon $(\mathrm{C})$. Their isotopic ratios $(R),{ }^{15} \mathrm{~N} /{ }^{14} \mathrm{~N}$ and ${ }^{13} \mathrm{C} /{ }^{12} \mathrm{C}$, respectively, are typically expressed as delta $(\delta)$ notation against an established standard as below.

$$
\delta X=\left[\left(\frac{R_{\text {sample }}}{R_{\text {standard }}}\right)-1\right] \times 1000
$$

The number is then multiplied by 1,000 to be expressed as "per mille ( $\% 0$ )." The standard notation for $\mathrm{N}$ and $\mathrm{C}$ is, therefore, $\delta^{15} \mathrm{~N}$ and $\delta^{13} \mathrm{C}$. 


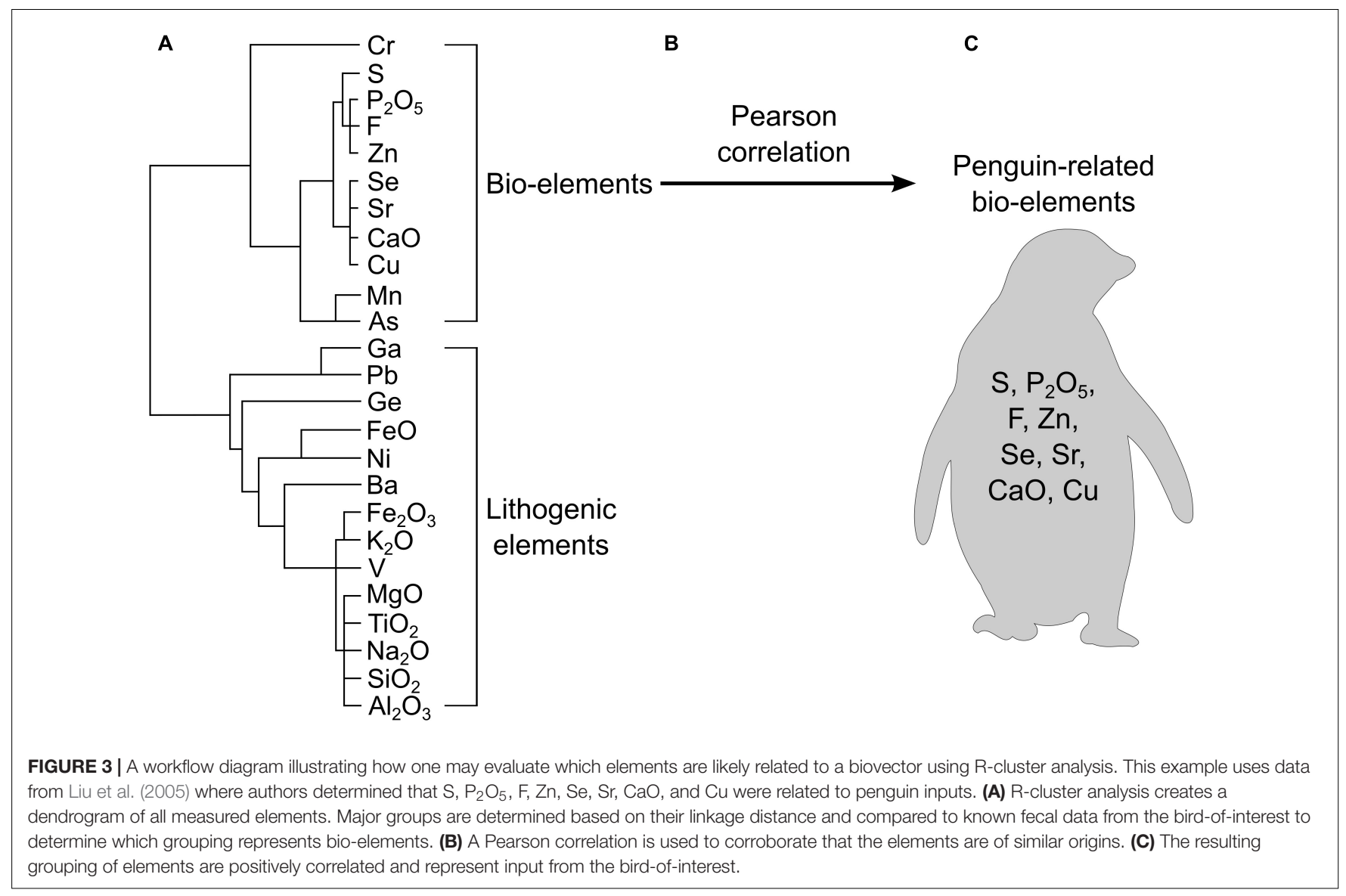

TABLE 1 | Contamination categories based on the index of geoaccumulation (Igeo), modified from Förstner et al. (1993).

\begin{tabular}{lc}
\hline Contamination intensity & Index of geoaccumulation $\left(\boldsymbol{I}_{\text {geo }}\right)$ \\
\hline Very high & $>5$ \\
High to very high & $4-5$ \\
High & $3-4$ \\
Moderate to high & $2-3$ \\
Moderate & $1-2$ \\
Unimpacted to moderate & $0-1$ \\
Practically unimpacted & $<0$ \\
\hline
\end{tabular}

Higher contamination intensity equates to higher enrichment by the biovector.

$\delta^{15} \mathrm{~N}$ values in sediments influenced by biovectors are enriched relative to reference conditions (i.e., atmospheric $\delta^{15} \mathrm{~N}$ ) because the heavier ${ }^{15} \mathrm{~N}$ isotope is retained in tissues by organisms during amino acid decomposition, whereas the lighter ${ }^{14} \mathrm{~N}$ isotope, because of its weaker bond with adjacent atoms, is preferentially excreted during transamination and deamination reactions (Adams and Sterner, 2000). This results in stepwise enrichment up the food web, averaging an increase of $\sim 3.4 \%$ per trophic level (Minagawa and Wada, 1984). In paleolimnology, the enriched $\delta^{15} \mathrm{~N}$ is deposited onto the landscape by a nearby bird colony or roost and is archived in sediments via avian guano carcasses, feathers, and eggshells. Therefore, a higher $\delta^{15} \mathrm{~N}$ value in sediments typically relates to greater bird numbers until a plateau is reached equal to the $\delta^{15} \mathrm{~N}$ value of the refuse (Duda et al., 2020a), with minor changes from environmental factors such as ammonification, remineralization, nitrification, and denitrification (e.g., Cifuentes et al., 1989; Savage et al., 2004; Torres et al., 2012). Since $\delta^{15} \mathrm{~N}$ is linked to the trophic status of the biovectors, the relative increase compared to background conditions is higher in upper-trophic-level organisms than in lower-trophic-level organisms (Michelutti et al., 2010b).

Changes in sedimentary $\delta^{15} \mathrm{~N}$ values have been used to successfully track bird colony sizes in Arctic (Michelutti et al., 2009; Yuan et al., 2010; Keatley et al., 2011; MacDonald et al., 2015; Davidson et al., 2018; Hargan et al., 2019; Ribeiro et al., 2021), Antarctic (Huang et al., 2014, 2016; Gao et al., 2018c; Yang et al., 2018), temperate (Stewart et al., 2015, 2019; Hargan et al., 2018; Duda et al., 2020a,c), and tropical (Conroy et al., 2015; Wu et al., 2017a, 2018) systems. Although this method is effective, Nie et al. (2014b) suggested an improvement on $\delta^{15} \mathrm{~N}$ as $\Delta^{15} \mathrm{~N}$, which is calculated as the difference between acid-treated and untreated $\delta^{15} \mathrm{~N}$. The authors highlight that $\Delta^{15} \mathrm{~N}$ can track ornithogenic signals more effectively than $\delta^{15} \mathrm{~N}$ in cold and arid environments that are subject to strong post-depositional processes such as guano deposition and ammonia-volatilization.

Although an indirect measure of avian inputs, changes in sediment $\delta^{13} \mathrm{C}$ values can also be used to track changes in seabird numbers. Instead of directly measuring inputs from guano, as is 
the case with $\delta^{15} \mathrm{~N}$, deviations in $\delta^{13} \mathrm{C}$ values may track changes in production linked with marine-derived changes in primary productivity. However, when considering recent changes in $\delta^{13} \mathrm{C}$ values, it is important to account for depleting atmospheric $\delta^{13} \mathrm{C}$ due to increased $\mathrm{CO}_{2}$ production from fossil fuel burning (known as the Suess Effect; Keeling, 1979). A common standardization method is to normalize to pre-1840 levels of $\delta^{13} \mathrm{C}$, based on the methods presented in Schelske and Hodell (1995). Once normalized, $\delta^{13} \mathrm{C}$ can have both a positive and a negative relationship with changes in the bird numbers, and therefore a thorough understanding of the system and the use of supporting proxies is recommended. Typically, $\delta^{13} \mathrm{C}$ values are positively correlated to colony size (i.e., ${ }^{13} \mathrm{C}$ is enriched as colony size increases). This relationship principally reflects an increase in primary production and organic matter introduction resulting from guano fertilization (Sun et al., 2000; Yuan et al., 2010; Liu et al., 2013; Conroy et al., 2015; Davidson et al., 2018; Gao et al., 2018c; Cheng et al., 2021). However, in some cases, $\delta^{13} \mathrm{C}$ values can also have a negative relationship with colony size (i.e., $\delta^{13} \mathrm{C}$ is depleted as colony size increases). For example, Liu et al. (2006b) linked the increase in penguin colony size to $\delta^{13} \mathrm{C}$ depletion, which was a result of vegetation trampling by the penguins and toxification from their guano, leading to a diminishment of the overall vegetation. Similarly, Duda et al. (2020a) noted that burrowing Leach's storm-petrels caused an accelerated rate of inorganic material delivery to the lake, which caused a depletion of $\delta^{13} \mathrm{C}$ as the colony increased in size.

Although less common, studies have also demonstrated the potential of $\mathrm{HCl}$-soluble strontium isotopes to track seabird guano inputs, and therefore changes in long-term population size (as ${ }^{87} \mathrm{Sr} /{ }^{86} \mathrm{Sr}$; Sun et al., 2005; Liu et al., 2007). Strontium isotopes are effective ornithological proxies that track the source of nutrients to an environment without transformation by biological or chemical processes (Miller et al., 1993). In penguin-influenced sediments from Antarctica, Sun et al. (2005) determined that the hydrochloric acid (HCL)-soluble ${ }^{87} \mathrm{Sr} /{ }^{86} \mathrm{Sr}$ reflected penguin guano ratios, whereas the $\mathrm{HCl}$-insoluble ${ }^{87} \mathrm{Sr} /{ }^{86} \mathrm{Sr}$ reflected bedrock ratios. These results, supported by a follow-up study (Liu et al., 2007), suggest that using HClsoluble ${ }^{87} \mathrm{Sr} /{ }^{86} \mathrm{Sr}$ can be used to track marine-derived nutrient enrichment from seabirds.

\section{Lipid Biomolecules}

Lipid biomolecules are water-insoluble fats produced by all biological life. Of particular interest in paleolimnological reconstructions are sterols and stanols. Sterols are natural, unsaturated steroid alcohols that represent an important group of compounds for the functioning and structure of biological membranes (Bretscher, 1973). Stanols are the reduction products of sterols by the process of hydrogenation, which is typically mediated by microbes in animal gastrointestinal tracts or in the environment (Reeves and Patton, 2001; Bull et al., 2002). Sterols and stanols are discharged in varying concentrations and combinations in the feces of animals (Leeming et al., 1996; Harrault et al., 2019) and are emerging as important proxies to directly track animal inputs to lake sediments over decadal- and century-scale periods (D'Anjou et al., 2012; Hargan et al., 2019; Schroeter et al., 2020; Cheng et al., 2021). In general, sterols and stanols are hydrophobic compounds with a high affinity for sorption onto organic matter and suspended particles, and therefore they typically become rapidly incorporated into sediments of aquatic ecosystems (Korosi et al., 2015). Once in the sediments, the degradation of fecal sterols is likely minimal (Bartlett, 1987; Benfenati et al., 1994), which makes them ideal for tracking changes in the abundance of seabirds over time.

Recent proof-of-concept studies have demonstrated that the ratio of cholesterol (cholest-5-en-3 $\beta$-ol) to the sum of cholesterol and sitosterol ( $\beta$-sitosterol), termed the "seabird index," tracked significant enrichment in pond sediments closest to a nesting colony of northern fulmars in the High Arctic (Cheng et al., 2016, 2021). This ratio is used to control for cholesterol in the sediment that is introduced from higher plants and algae as opposed to having ornithogenic origins (Cheng et al., 2016). Furthermore, enrichment in a similar seabird index was observed in temperate ponds receiving fecal inputs from waterbirds with higher trophic positions (Hargan et al., 2018). Unlike in the Arctic and sub-Arctic locations, where transformations of sterols in the environment are largely limited by the cold temperatures and short growing seasons, sterols in temperate locations may undergo hydrogenation to stanols in the environment. Thus, Hargan et al. (2018) expanded the seabird index for tracking waterbird (i.e., double-crested cormorant (Phalacrocorax auritus) and ring-billed gull (Larus delawarensis)) populations from the sediments of shallow, temperate ponds, by including cholesterol and sitosterol and their microbially reduced products, $5 \alpha-$ cholestanol and stigmastanol, respectively. Overall, the use of these new seabird sterol indices has been validated through significant correlations with other traditional and independent seabird proxies (Cheng et al., 2016; Hargan et al., 2018; Yang et al., 2021). These studies indicate that both cholesterol concentrations and the "seabird sterol indices" can provide an indirect measure of seabird presence in sediment cores from lakes and ponds where seabird-derived enrichment is evident. These lipid proxies, especially when considered as part of a multi-proxy framework that also includes $\delta^{15} \mathrm{~N}$ and biogenic elements, can be useful to infer avian population trends through time (Hargan et al., 2019; Duda et al., 2020b,c; Yang et al., 2021).

\section{Diatoms}

Bird colonies can dramatically alter the limnological conditions of receiving waterbodies (Otero et al., 2018). These limnological changes typically include increased concentrations of nutrients, metals, and dissolved organic carbon. Diatoms (Class: Bacillariophyceae) are microscopic, single-celled eukaryotic algae found in most wet habitats in the world. Changes in diatom assemblage composition are the most commonly used approach to track changes in water quality in paleolimnological assessments, as they are ideal indicators of ecosystem change (Smol and Stoermer, 2010) because their taxonomically identifiable siliceous cell walls are typically well-preserved in a broad spectrum of sediments (Battarbee et al., 2001). Importantly, diatom taxa have well-documented environmental optima and tolerances, which can be used to infer changes 
in nutrients, $\mathrm{pH}$ and other limnological variables potentially influenced by bird inputs.

Typically, with the introduction and/or growth of a seabird colony influence, the diatom assemblage inhabiting a body of water will shift from taxa indicative of low nutrients to those indicative of high nutrients (e.g., Brooks et al., 2012; Stewart et al., 2015, 2019). In other instances, depending on the species producing the seabird guano and conditions of the surrounding ecosystem, the diatoms can also reflect changes in $\mathrm{pH}$ (Duda et al., 2020a,c) or conductivity (Duda et al., 2019). Given their ubiquity, diatoms have been successfully used to draw inferences about historical seabird populations around the world (Michelutti et al., 2009; Keatley et al., 2011; Brooks et al., 2012; MacDonald et al., 2015; Stewart et al., 2015, 2019; Roberts et al., 2017; Wasiłowska et al., 2017; Luoto et al., 2019; Duda et al., 2020a,c).

\section{Invertebrate Sub-Fossils}

The most common invertebrate indicators used in paleolimnology are chironomids (Order: Diptera), Cladocera, and Ostracods (Class: Crustacea). The remains of other invertebrates and larger organisms, such as fish, are often not abundant in sediments and typically do not have enough direct ecological link to seabird inputs to act as effective paleolimnological proxies.

Chironomid larva are the most abundant insect remains in lake sediments (Hall and Herhardt, 2002). Paleolimnologists use the distinct chitinous mouthparts and head capsule characteristics to identify remains. As ecological indicators for biovector reconstructions, chironomid communities are predominantly used to infer changes in bottom-water oxygen, acidity, and metal concentrations (Walker, 2001). As a bird colony grows in size, several limnological changes that affect the assemblage composition of chironomid larvae may occur. For example, increased nutrients typically result in increased algal biomass (i.e., increased organic matter), which in turn may increase benthic respiration/decomposition, leading to lower deepwater oxygen concentrations or even anoxia. Chironomids can also be affected by changes in $\mathrm{pH}$ and metal concentrations introduced by seabird guano. Changes in chironomid subfossil assemblages have been used to infer long-term changes in different seabird populations (Michelutti et al., 2011; Luoto et al., 2019; Duda et al., 2020a,c; Lim et al., 2021), but often, in oligotrophic ecosystems, production is so low that head capsule remains are too few to adequately characterize assemblage composition (Quinlan and Smol, 2001). In such low productivity ecosystems, increases in head capsule concentration and diversity have been related to enhanced food availability from seabird nutrient introductions (Michelutti et al., 2009; Brooks et al., 2012; Luoto et al., 2014, 2015; Stewart et al., 2020).

Compared to chironomids, other invertebrate sub-fossils have been sparsely used to reconstruct changes in lake water characteristics linked to bird populations. Ostracod communities respond to changes in nutrient concentrations, but their identifying shells rarely preserve well in acidic conditions (Holmes, 2001). Similarly, cladoceran community structure can respond to habitat changes and lake trophic status. To date, however, higher abundances of Cladocera have mainly been linked to track increased food availability (i.e., higher productivity) resulting from avian nutrient enrichment (Griffiths et al., 2010; Luoto et al., 2014, 2015).

\section{Terrestrial Pollen and Non-pollen palynomorphs}

Avian nutrient inputs typically also have a significant influence on terrestrial ecosystems; however, the nature and magnitude of these influences can be highly variable depending on the quantity and quality of the inputs, as well as the receiving environment. In some environments, avian-derived nutrients enhance productivity, resulting in a more fertilized, productive, and diverse ecosystem (Anderson and Polis, 1999; Croll et al., 2005). Alternatively, too much nutrient deposition can result in reductions in vegetation and seed bank richness, as observed on some islands inhabited by double-crested cormorants (Boutin et al., 2011).

Regardless of the type of influence, changes to the terrestrial environment preserved in nearby lake sediments can be used to make inferences about the seabird population size. There are two methods to understand past changes in vegetation: palynology and macrofossil analysis. Palynology is the study of microscopic pollen and non-pollen palynomorphs (NPP, or microfossils on pollen slides that are not pollen, taxonomically belonging to a wide variety of fungi, animals, algae, and plants), while macrofossil analysis examines a variety of vegetative remains, such as seeds, twigs, and leaves. Generally, palynology is preferred over macrofossil analysis as pollen and NPP are much more abundant and taxonomically identifiable in sediments. However, macrofossils are occasionally used in paleolimnological studies to understand changes in local vegetation (reviewed in Birks, 2001).

Various paleolimnological studies have used palynology to make inferences about long-term changes in avian populations. For example, Conroy et al. (2015) used a combination of changes in $\delta^{15} \mathrm{~N}$ and $\delta^{13} \mathrm{C}$ values with pollen concentrations in lakes from the Galápagos Islands to make inferences about marine productivity and long-term changes in seabird population size. The authors described a positive relationship between increasing red-footed booby (Sula sula) numbers and red mangrove (Rhizophora mangle), the dominant plant species in the study region. Conroy et al. (2015) found that the seabirds provided the nutrients needed for an increase in the mangrove abundance. The mangrove pollen, alongside $\delta^{15} \mathrm{~N}$ and $\delta^{13} \mathrm{C}$ measurements, provided a more robust understanding of the booby colony trends.

There are also more direct palynological proxies of seabird inputs. Spores of Sporormiella, an obligate coprophilous fungus, have been used to track mammal populations over long periods (Davis, 1987). However, these fungal spores could also be used to show long-term changes in the population size of endemic avian populations (Wood et al., 2011). Fungal hyphae are another example of a palynological proxy for seabird presence, as hyphae are nearly exclusively terrestrial in origin and are not typically observed in aquatic environments. However, in a study examining the effects of Leach's storm-petrel dynamics on the terrestrial environment, the authors linked the presence 
of fungal hyphae in the sediments to the presence of stormpetrels (Duda et al., 2020b). This relationship exists because storm-petrels are burrow-nesting seabirds that disturb soils and increase the availability of terrestrial components, which are then introduced into a body of water during runoff events.

\section{Pigments}

As birds introduce nutrients to an ecosystem, they typically also increase the overall primary production and alter the algal communities in any affected water column. However, unlike siliceous diatom valves and chrysophyte cysts, most soft-bodied algae do not preserve well in sediments. Therefore, a more complete picture of aquatic phototroph community composition can be inferred from directly measuring fossil pigments preserved in sediments (Leavitt and Hodgson, 2001) or using inferred pigment concentrations derived from visible and near-infrared spectroscopy (VNIRS). A commonly used pigment is chlorophyll- $a$, which is generally considered a robust indicator of whole-lake production (Michelutti et al., 2010a; Keatley et al., 2011; Chen et al., 2013; Stewart et al., 2015, 2019; Michelutti and Smol, 2016; Duda et al., 2020b,c). Other pigments related to diatoms (e.g., diatoxanthin) and cyanobacteria (e.g., echinenone, myxoxanthophyll) have also been linked to seabird enrichment in the Arctic (Keatley et al., 2011). Similarly, declines in the concentrations of aphanizophyll and canthaxanthin, pigments related to nitrogen-fixing cyanobacteria, have been correlated to a supplemented nitrogen supply related to burgeoning geese populations (MacDonald et al., 2015). In other cases, variations in the full range of reflectance as identified by VNIRS have been used to infer past seabird population sizes (Liu et al., 2011; Xu et al., 2012, 2019; Wu et al., 2017a,b, 2018).

\section{Supporting and Novel Proxies}

Numerous other proxies are generally not considered effective to reconstruct colony trends when used independently; however, when coupled with other proxies, they can provide compelling collaborative evidence for changing bird populations. For example, because bird inputs typically increase primary production and therefore the organic matter in the ecosystem, the loss-on-ignition (LOI, literally the amount of combustible material) has been used to identify changes in organic content of the sediments (Brooks et al., 2012; Luoto et al., 2014, 2015; MacDonald et al., 2015; Gao et al., 2018b; Yang et al., 2019). Similarly, magnetic susceptibility, or changes in the magnetism of sediments that are correlated to changes in particle size, can be associated with increased erosion caused by birds disturbing shorelines and catchments (Luoto et al., 2014, 2015; Nie et al., 2015). Finally, $n$-alkanoic acids (often as $n$-alkyls) are lipid biomarkers that originate from the tissues of organic matter. As the carbon chain length differs depending on the source (Chen et al., 2020a), it is possible to associate the known influences of a bird colony on the environment to changes in $n$-alkyl variety and abundance. Often, short-chain $n$-alkyls (e.g., $\mathrm{C}_{18}, \mathrm{C}_{24}$ ), which are proxies of aquatic moss and algae, have been used to make inferences on changes in colony size as bird droppings provide the nutrients for moss and algae proliferation (Wang et al., 2007; Huang et al., 2010; Hu et al., 2013).
New proxies that strengthen overall colony size reconstructions and associated inferences are continually established. For example, Zheng et al. (2015) used differences in stable mercury isotope fractionation $\left(\Delta^{199} \mathrm{Hg} / \Delta^{201} \mathrm{Hg}\right)$ to identify bioaccumulation pathways in sediments that accumulated inputs from penguins and seals. Chen et al. (2020b) identified that penguins increase the amount of organic and acid volatile $S$ relative to sulfate and pyrite $S$. Lastly, Nie et al. (2014a) linked temporal trends in the concentration of rare earth elements with penguin populations.

\section{CASE STUDIES: APPLICATIONS OF SEDIMENT ARCHIVES IN AVIAN CONSERVATION BIOLOGY}

Paleoecological reconstructions of bird colonies provide population managers with new insights regarding changes in bird colonies over timescales vastly predating anything available using modern monitoring methods. These reconstructions offer an opportunity to address a range of questions that have the potential to inform conservation and management strategies for populations of concern.

\section{How Dynamic Are Populations on Long-Term Timescales?}

As many bird species are long-lived and highly mobile, they have the potential to form metapopulations (i.e., networks of local populations that are connected by dispersal of individuals; Esler, 2000). Metapopulations are vital in sustaining viable and effective population sizes when faced with local and regional stressors as well as taking advantage of favorable conditions when they emerge. Local stressors include changing habitat availability and influxes of predators, while regional stressors include a variety of forces, including changes in climate and ocean currents. As described below, paleolimnological approaches can be used to assess the effects of local and regional influences on bird colonies on the scale of decades to millennia; leading to an understanding of metapopulation dynamics.

Recent paleolimnological work on Antarctic penguin colonies has revealed the importance of natural phenomena relating to population size. At a local scale, Gao et al. (2018c) used $\sim 1,600$-years of changes in $\delta^{15} \mathrm{~N}$ and $\delta^{13} \mathrm{C}$ values, as well as geochemistry from lake sediment cores, to show that the Adélie penguin colonies in the Vestfold Hills of East Antarctica were largely controlled by krill abundance, which itself is correlated to trends in solar minima and maxima as inferred from a nearby ice core. This relationship occurs because increases in total solar irradiance (TSI) results in increases in energy flux to the oceanic ecosystem and thus increases phytoplankton biomass and primary productivity. This bottom-up increase changes the food web to support a greater number of penguins (Saba et al., 2014).

Regional influences can also drive changes in the bird population. Near the Antarctic Peninsula, Roberts et al. (2017) used a $\sim 8,500$-year paleolimnological record from Ardley Island 
to identify maxima in penguin populations that were nearly extirpated by eruptions of the Deception Island volcano. Using dated ash (i.e., tephra) layers and a variety of proxies to reconstruct the penguin colony trends, the authors concluded that poisonous aerosols (e.g., $\mathrm{SO}_{2}, \mathrm{~F}$ ) and trace elements (e.g., $\mathrm{Cd}, \mathrm{As}$, and $\mathrm{Pb}$ ) from the initial volcanic eruptions, followed by the smothering effects of ash deposition and prolonged exposure to abrasive glass particles while rearing and feeding, probably caused the site-wide population decline. Notably, the penguin population recovered at this site after $\sim 400$ to 800 years (Roberts et al., 2017).

For some bird populations, a combination of local and regional drivers can cause dramatic changes in colony size. On islands in the Northwest Atlantic Ocean, paleolimnological reconstructions of Leach's storm-petrel colonies have suggested intercolonial movement as an important behavior favoring long-term persistence (Duda et al., 2020a,c). Using several sediment cores and multiple proxies (Supplementary Table 1) from lakes draining the two major storm-petrel colonies on Baccalieu Island (Newfoundland and Labrador, Canada) and Grand Colombier Island (St. Pierre and Miquelon, France), the authors reconstructed up to $\sim 5,800$ years of population dynamics. Although these two sites are only $\sim 270 \mathrm{~km}$ apart, the two colonies peaked in storm-petrel numbers at different times (Figure 4). These paleolimnological data, combined with natural history observations (Pollet et al., 2020) and genetic studies (Paterson and Snyder, 1999; Bicknell et al., 2012), strongly indicate that Leach's storm-petrels require a network of interconnected colonies to maintain the metapopulation. Possible drivers of these fluctuations may include local factors, such as predators and suitable habitat availability, or regional changes, such as shifts in the Labrador Current. Regardless of the driver(s) of population size, long-term data, such as those provided by lake sediments near nesting colonies, are the only known means to explore natural population dynamics over long periods that predate modern monitoring programs. Understanding colony dynamics before human arrival can also address shifting baseline syndrome in conservation biology by providing longer temporal records for contemporary population trends (e.g., Soga and Gaston, 2018). For example, the available colony size estimates for Leach's storm-petrels on Baccalieu Island from 1984 (Sklepkovych and Montevecchi, 1989) and 2013 (Wilhelm et al., 2020) indicated that the colony has been in decline since the 1980s. The paleolimnological data corroborated the decline, but also showed that the colony size in the 1980s was at its highest in nearly two millennia. Therefore, had the original 1980s survey been conducted earlier, in the 1960s for instance, the storm-petrel colony would have appeared to be stable compared to 2013 (Figure 4). Moreover, had the original 1980 s survey been conducted in the early 1800 s, the colony would have appeared to be increasing in size (Figure 4). In contrast, the Grand Colombier colony appeared to be stable based on four surveys since the 1980s. However, when the timescale was pulled back, it was clear that the colony is now only a fraction $(\sim 16 \%$ of the potential carrying capacity) of what was possible before permanent European settlement in the 19th century (Figure 4; Duda et al., 2020a).
These studies provide the opportunity to consider bird population changes before human interferences and in the context of a larger, dynamic population that may be declining as part of natural cycles. Whether a population is currently increasing or decreasing is no longer a sufficient indication of status; identifying when the natural dynamics are disrupted becomes the goal in population monitoring. For example, a colony may be increasing in numbers but only as a result of shortterm environmental conditions that are optimal for the species and thus conservation action may still be warranted. Similarly, a colony may be declining in numbers but may still remain within natural population variability over longer periods. Under these circumstances, a management approach that maintains these ordinary fluctuations and does not focus on the recent declines may be the most effective strategy.

\section{How May Populations Respond to Climate Change?}

Because of the multifaceted ecological changes related to recent climate warming, it is difficult to predict how bird populations may respond (Mason et al., 2019). In some regions, warming may result in increased abundance and range expansion (e.g., Frishkoff et al., 2016). By the same token, climate warming may result in changes in vegetation that may have adverse habitats for different taxa (e.g., Kuussaari et al., 2009). How can we predict changes in seabird populations with future warming and thereby provide the most effective conservation and management? Reconstructing how bird populations responded to past known climate events may act as a guide to future changes.

A series of paleoenvironmental reconstructions of Antarctic penguin colonies have identified the colonization dates and periods of "penguin optima" (originally coined by Baroni and Orombelli, 1994), during which penguin populations boomed in response to warmer and wetter climates during the Holocene (Figure 5). The timing of penguin arrival in the Antarctic varies by region but appears to be linked to increased availability of breeding habitat and open-water conditions coinciding with deglaciation (Emslie et al., 2007; Gao et al., 2018a). Post colonization, the period of penguin optimum has also varied depending on the study region (Huang et al., 2009a; Figure 5) but generally occurs during the late Holocene, from $\sim 2,000$ to 4,000 years BP (Huang et al., 2009a; Sun et al., 2013). Based on several paleolimnological studies, Adélie penguins prefer warmer periods with deglaciation and larger ice-free areas for better prey conditions (Huang et al., 2009a; Gao et al., 2018c). However, the potential benefits of climate warming observed in the past may have already been exceeded. In the Ardley Peninsula, south of Tierra del Fuego, the colony of gentoo, Adélie, and chinstrap penguins that had been stable for the last $\sim 1,300$ years appears now to be in decline (Liu et al., 2005).

Seabird populations in the tropics have recorded more variable responses to past climates than those occurring in polar regions. In the Xisha Islands (or Hoàng Sa in Viet Nam), the dominant red-footed booby colony reached maximum size during the cooling period of the Little Ice Age (1400 to 

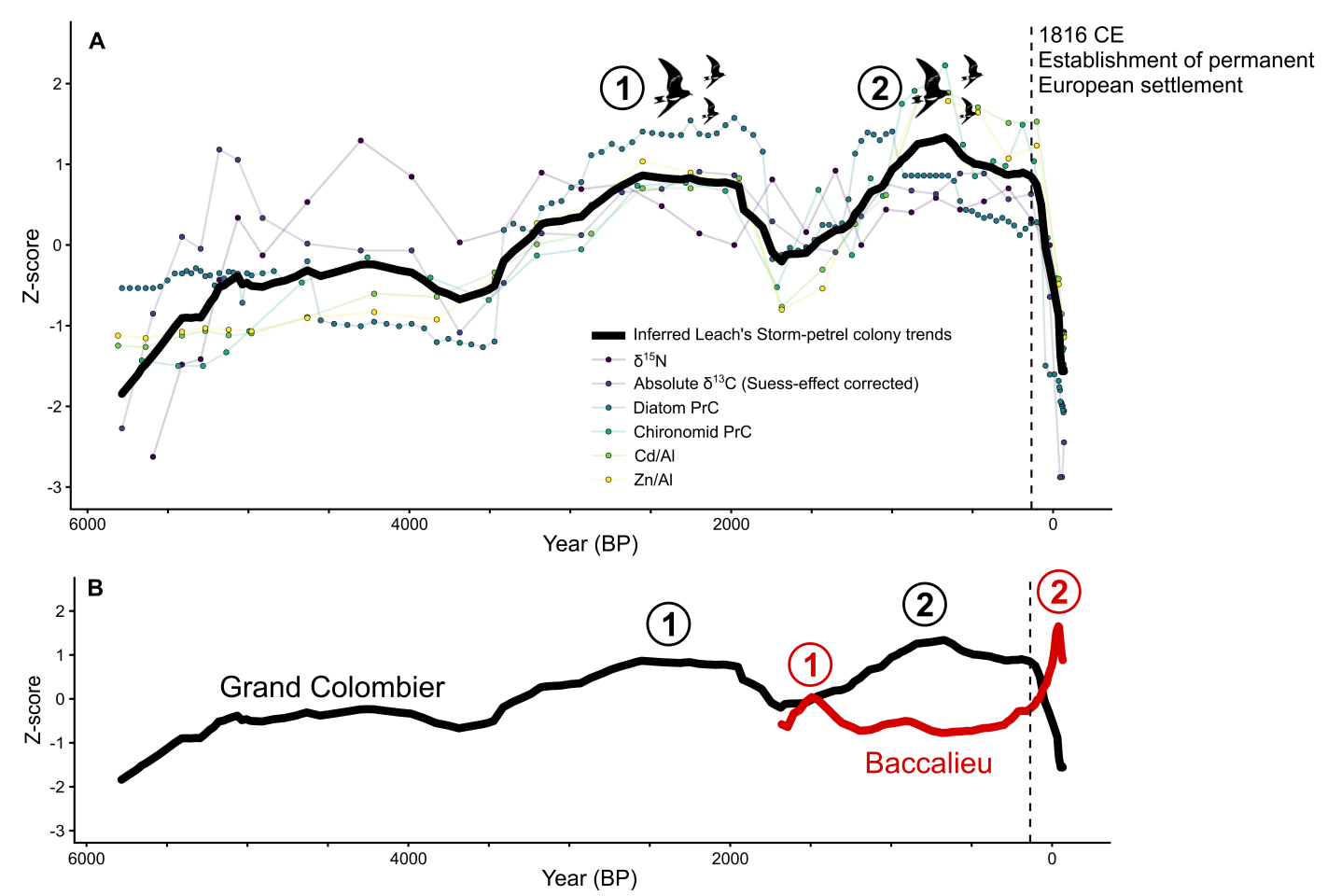

FIGURE 4 | Long-term population trends of Leach's storm-petrel colony dynamics from Grand Colombier Island and Baccalieu Island from the Northwest Atlantic Ocean (Duda et al., 2020a). (A) Overall trends in the Grand Colombier Island Leach's storm-petrel population as determined by the mean of all measured paleolimnological proxies. (B) Trends of Grand Colombier Island contrasted to 1,700 years of population trends on Baccalieu Island, as detailed in Duda et al. (2020c). The distinct peaks in the storm-petrel colony size are identified numerically. Note that the rapid population decline is concurrent with the European population expansion in the St. Pierre and Miquelon archipelago, beginning in $1816 \mathrm{CE}$.

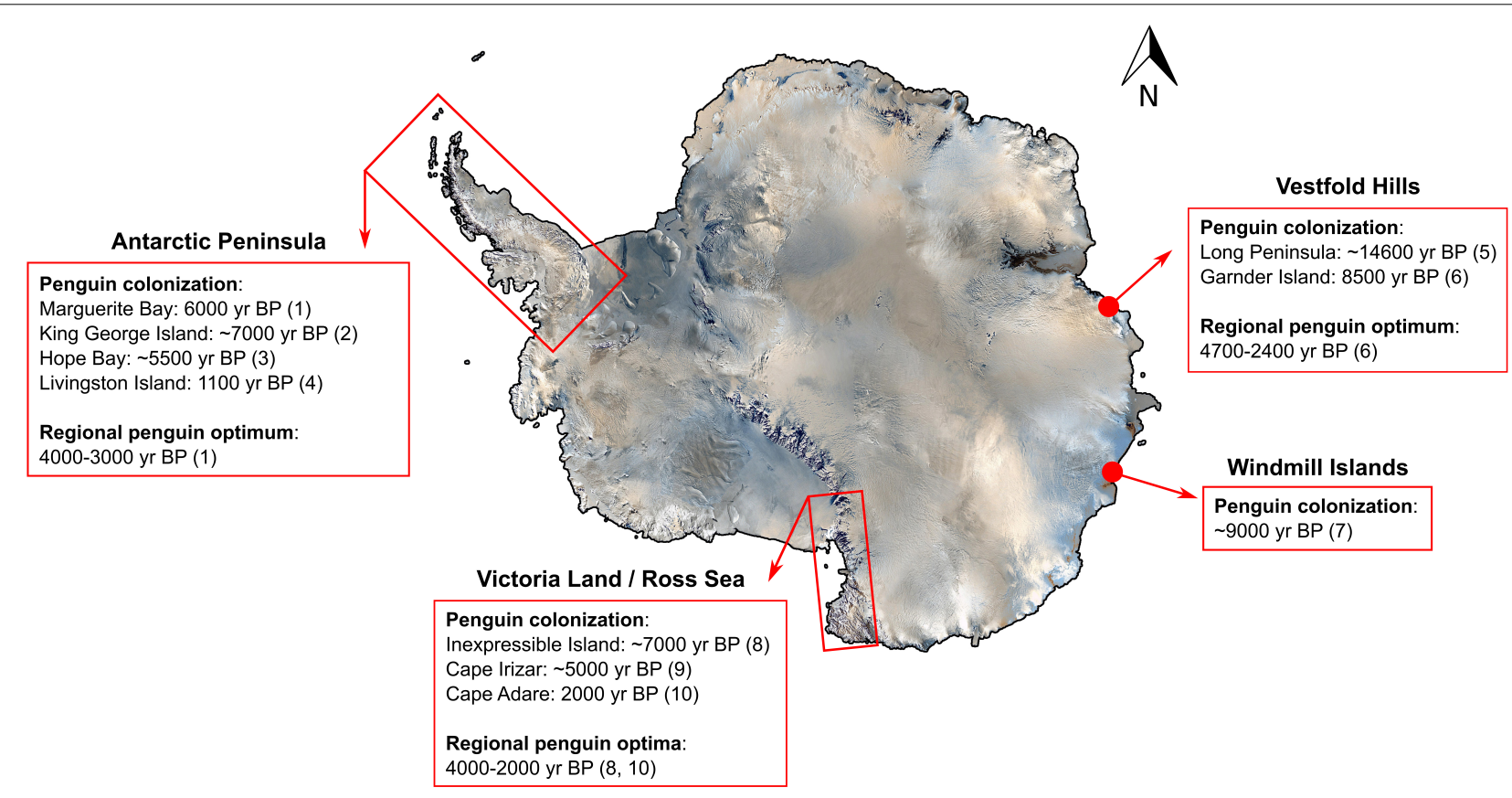

FIGURE 5 | Earliest penguin colonization and regional optima since the last Antarctic glaciation period. Modified and updated from Huang et al. (2009a) and Sun et al. (2013). References include (1) Emslie and McDaniel (2002); (2) Emslie et al., 2020; (3) Zale, 1994; (4) Emslie et al., 2011; (5) Gao et al., 2018a; (6) Huang et al., 2009b; (7) Emslie and Woehler, 2005; (8) Emslie et al., 2007; (9) Emslie, 2021; and (10) Emslie et al., 2018. 
$1850 \mathrm{CE}$ ) (Xu et al., 2016). In contrast to what was observed in the Antarctic, cooling may have had a positive influence on the seabird abundance in the tropics. For example, the expansion of ice cover in polar regions can increase marine primary productivity and food availability (Liu et al., 2002; Shiozaki and Chen, 2013; Xu et al., 2016). Similarly, on Dongdao Island (or Đảo Linh Côn in Viet Nam) from the same Xisha Islands archipelago, the bird population peaked at multiple times over the $\sim 1350$-year record in correspondence to reconstructed sea surface temperature (SST) below $27^{\circ} \mathrm{C}$ (Liu et al., 2006c). The authors indicated that a likely reason for the increased seabird abundance was better food supplies. Given the complex interactions of changing climates with entire marine ecosystems, hindcasting may provide some of the most effective predictions of the future of seabird dynamics. A key benefit of hindcasting population changes is that it covers far longer periods of environmental variation and is largely free from human influences (depending on the location and length of the time series) when compared to modern monitoring programs, which typically incorporate the impacts by human interference as an additional factor, alongside current climate change.

\section{How Have Populations Responded to Human Intrusion?}

Before regular wildlife surveying began, the double-crested cormorant population in Lake Ontario was nearly extirpated as a result of dichlorodiphenyltrichloroethane (DDT) exposure (Wires and Cuthbert, 2006). However, following conservation efforts and the ban of DDT, the cormorant population grew from $\sim 136$ breeding pairs in the 1970 s to over 100,000 in the early 2000s (Weseloh et al., 2012). Because of this rapid growth and lack of pre-decline monitoring, cormorants were blamed for negatively impacting sport fishing and destroying natural habitats. Government programs aimed at reducing the cormorant populations (e.g., culling, extended hunting programs) were instigated in 2020 (Hobson, 2021). However, without long-term monitoring data, the question remained: What is "normal"? What were population numbers like before significant human interventions? Using a combination of paleolimnological proxies (Supplementary Table 1), it became evident that the modern cormorant population is currently larger than it has been in at least the last $\sim 150$ years (Stewart et al., 2015, 2019). With these data, it is possible to estimate the historical size of cormorant populations and also consider the differences in the new environment driven by increasing anthropogenic influence, which together can be used to help set informed and achievable management goals. Although paleolimnological data suggested that the current double-crested cormorant population in Lake Ontario is now more numerous than in the past $\sim 150$ years, the large colonies are principally supported in the new environment by introduced and nuisance warm-water fish species that are growing in numbers due to climate change, such as round goby (Neogobius melanostomus) and alewife (Alosa pseudoharengus) (Madura and Jones, 2016). By preying on these warm-water fish species, it could be argued that cormorants act as a biological control that contributes to maintaining natural biodiversity and supports commercially valuable native cold-water taxa, such as lake trout (Salvelinus namaycush) and lake whitefish (Coregonus clupeaformis) (Johnson et al., 2010, 2015).

Common eider (Somateria mollissima borealis) is a culturally and economically important northern sea duck, but limited survey data exist at the more remote portions of its range, such as the Canadian Arctic and West Greenland. However, the available information suggested that the West Greenland breeding population had declined by $\sim 81 \%$ over 40 years (Merkel, 2004). Given the lack of regular surveying and numerous potential drivers of the decline (e.g., climate warming, increased hunting pressures), it was challenging to provide informed management advice for a species that supports an important Indigenous harvest. In response, Hargan et al. (2019) used a paleolimnological approach to supplement available records to elucidate the cause of decline (Figure 6). With a reconstructed population record, now up to $\sim 400$ years long, it was clear that the eider declines coincided with a growing human population with higher hunting efficiency due to increased access to firearms and motorized vehicles. From this research, it was apparent that harvest was a strong driver of this population and that this would need to be considered when setting harvest regulations in the future.

\section{CURRENT LIMITATIONS AND POTENTIAL SOLUTIONS}

Long-term studies provide very high value in informing policy that can directly address modern ecological issues (Hughes et al., 2017). However, long-term studies are limited due to the substantial time and labor required to sustain the work. As a result, most surveying begins only after a population has experienced a noticeable change, and thus it becomes difficult to consider the natural, long-term dynamics of a species before human interference. Recent developments in paleoecological approaches have made substantial improvements to the application and interpretation of long-term population changes. However, there remain potential advancements for the development of proxies, ecologically important populations to explore, and other challenges to overcome. The following describes potential future directions of paleolimnological reconstructions of populations.

\section{What Is the Relationship Between Paleolimnological Proxies and Absolute Colony Size?}

Currently, paleolimnological inferences of colony size represent indices that generally reflect relative trends (i.e., timing and magnitudes of change) and cannot yet be used to definitively assign absolute numbers of birds at a site. This limitation is due to the complex and indirect relationship between bird inputs and the observed changes in sediments. For an estimation of past seabird numbers, several variables, such as the number of birds 


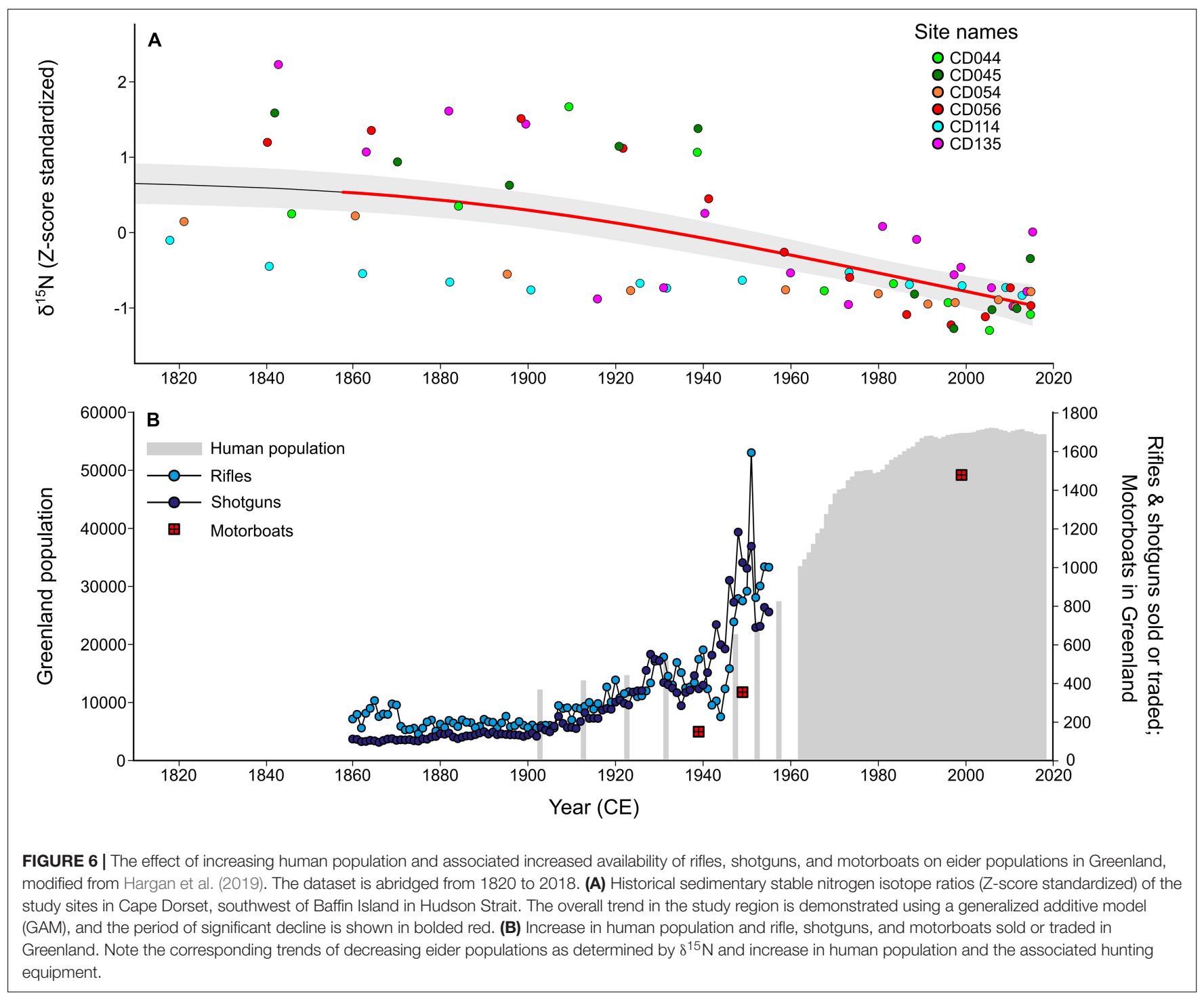

in the waterbody's catchment, the amount of refuse produced per bird, and post-depositional processes need to be estimated. This estimation is further complicated by the non-linear relationship between bird inputs and paleolimnological proxies [e.g., $\delta^{15} \mathrm{~N}$ has a logarithmic relationship with bird numbers, reaching a plateau at the $\delta^{15} \mathrm{~N}$ value of the species' guano (Duda et al., 2020a)].

To overcome these limitations, researchers have developed a variety of methods to summarize the paleolimnological data to estimate the trends in colony size. For instance, statistical techniques such as "Q-factor analysis" can provide information on changes in the relative abundance of bird-related bio-elements in the core, and this can be used to infer relative changes in colony size (e.g., Liu et al., 2006c; Huang et al., 2009a). Similarly, multiple proxies have been combined using an algorithmic mean of standardized data to provide an understanding of changes in colony size relative to the data available in the sediment core (Duda et al., 2020a,c). Building on this, Roberts et al. (2017) modelled colony sizes with wide confidence intervals for penguins breeding on Ardley Island in the Antarctic, and Duda et al. (2020a) used known habitat-specific bird densities to estimate the relative difference between modern and past colony size for a colony of Leach's storm-petrels breeding on Grand Colombier Island in the Northwest Atlantic Ocean.

Ground-truthing of paleolimnological reconstructions against well-understood, long-term surveying data is required to further develop the relationships between proxies and bird numbers. Although some studies have corroborated survey data with paleolimnological data (e.g., Duda et al., 2020c), monitoring data are typically very limited on timescales relevant for paleoecological comparisons. However, some bird colonies with a well-established, long-term monitoring program could provide the data required to calibrate the relationship between paleolimnological proxies and seabird numbers. For example, the wandering albatross (Diomedea exulans), breeding on Bird Island of South Georgia Island, has been monitored since 1961 (Wooller et al., 1992; BirdLife International, 2017) 
and has nearby freshwater bodies that may be viable for paleolimnological reconstruction.

\section{Availability of Sampling Locations}

Paleolimnological reconstructions are currently limited to locations where biovector inputs drain and are preserved in a nearby body of water. The body of water must be deep enough so that it does not experience significant mixing of the sediments by strong winds or storms. Further, the body of water cannot be too big, as this would result in the avian inputs being dwarfed compared to those from the environment. However, the paleolimnological techniques described in this review are not limited to bodies of water and can be expanded to peatlands and directly to guano deposits. For example, recent work has effectively used peat deposits, which may occur in locations without bodies of water, to track various seabirds using the North Water polynya in northwest Greenland (Outridge et al., 2016; Davidson et al., 2018) and seabirds nesting on the Falkland Islands (or Islas Malvinas in Argentina) (Groff et al., 2020). Similarly, some species produce geochronological accumulations of wastes based on their roosting behavior. For example, a study of accumulated guano and egested insect remains from a chimney swift (Chaetura pelagica) roost in Kingston, Canada, revealed that DDT application diminished Coleoptera (i.e., beetle) abundance, which altered insect communities and reduced the population size of the insectivorous swift and probably other aerial insectivores (Nocera et al., 2012). Beyond chimney swifts, other bird species that produce substantial accumulations of guano that can be explored using paleoecological techniques, such as gyrfalcon (Falco rusticolus) from Greenland (Burnham et al., 2009) and, potentially, oilbirds (locally known as guácharo; Steatornis caripensis) and Guanay cormorants (Leucocarbo bougainvilliorum).

Numerous regions remain unexplored. Based on our review of 69 studies that explored accessing avian dynamics using sediment cores (Supplementary Table 1), we found that the majority were from Antarctica $(n=36$, or $52 \%)$ and North America $(n=16$, or $23 \%)$. The remaining continents are less well studied, with relatively few studies in Asia $(n=10$, or $14 \%)$, Europe $(n=5$, or $7 \%)$, Oceania ( $n=1$, or $1 \%)$, South America $(n=1$, or $1 \%)$, and Africa $(n=0)$. This geographical spread suggests that using lake sediments for population reconstruction is in its infancy and there remain many more colonies and sites to examine (Otero et al., 2018). The methodology, however, is entirely transferable to other regions, and the only requirement is a sediment archive that receives significant biovector inputs.

\section{Sensitivity to Migration and Movement}

A paleolimnological reconstruction from a single site is not sensitive to animal movements. In other words, it is impossible to determine whether a colony has truly declined in numbers or has simply relocated on the basis of a single sediment core. However, this issue can be remedied through the use of multiple sediment cores that span an entire island or multiple sites within a bird-inhabited region. Then, concurrent changes across multiple sites may suggest region-wide shifts in colony size, whereas asynchronous declines may suggest colony relocation.
For example, synchronous shifts in multiple sediments cores have been used to establish both increases (e.g., Stewart et al., 2015, 2019) and decreases (e.g., Hargan et al., 2019; Duda et al., 2020c) in a bird population size. In contrast, asynchronous changes in sediment cores were used to establish colony redistribution (Duda et al., 2020a). Therefore, whenever possible, we recommend that multiple sediment cores from a study region influenced by the target species be examined.

\section{Mixed Species Signals}

Often, seabird colonies consist of several species and thus the paleolimnological signal is a mixture of all seabirds. Although not intrinsically a problem, conservation questions are often directed at a specific species rather than overall seabird numbers. This concern must be addressed when examining past trends, where the assumption is made that the inferred trends are representative of the same species throughout the record. To address this issue, we recommend using markers that may be more specific to the species of interest, such as geochemistry that relates to the organism in question or more broadly using sterol and stanol concentrations. For example, on islands in Lake Ontario, the inputs from double-crested cormorants and ringbilled gulls could be distinguished based on differences in their diets (Hargan et al., 2018; Stewart et al., 2020). Paleolimnological proxies that are more species-specific should continue to be developed to further distinguish the inputs from various species (see "Environmental DNA" and "Bile Acids").

\section{POTENTIAL ADVANCEMENTS IN THE FIELD}

\section{Environmental DNA}

Although several paleolimnological proxies have been established to effectively explore animal population dynamics, others are still being developed. For instance, environmental DNA (eDNA), sometimes called sedimentary DNA (sedDNA) or sedimentary ancient DNA (sedaDNA), has recently emerged as a potentially valuable proxy to understand changes with high taxonomic resolution (Domaizon et al., 2017; Capo et al., 2021). The eDNA archived in sediments can be from a variety of biological sources, such as animals, microbes, and vegetation, and understanding species changes in these various taxonomic groups can provide a holistic understanding of how the species affected the ecosystem. Although eDNA has not been used to track changes in avian population size, analogous studies have established the efficacy of the technique. For example, Giguet-Covex et al. (2014) used DNA metabarcoding of lake sediments to identify the presence and absence of mammal and plant DNA over the last $\sim 6,500$ years, for the purpose of identifying periods of overgrazing by agricultural fauna and deforestation by the human population. This study established the ability to track changes in animals and vegetation using sedDNA, and similar approaches can be extended to avian inputs. However, methodological limitations and problems with sedDNA preservation remain important challenges to overcome (Capo et al., 2021). Alternatively, instead of directly tracking animal inputs, it may be possible to use 
eDNA to identify microbes introduced to the lake ecosystem or indirectly infer changes in avian colony size based on trends in the past microbial community. For instance, it may be possible to identify unique microbes of avian intestines and feces, whose presence in sediments may indicate avian inputs. One such bacterial genus is Catellicoccus, which is ubiquitous in the gut microbiome of numerous avian species, including the colonial thick-billed murre (Uria lomvia) (Góngora et al., 2021). The presence of Catellicoccus has been used to track gull fecal contamination in coastal environments (Sinigalliano et al., 2013) and, by extension, it may be possible to track avian trends if it were present in sediments.

Alternatively, changes in microbial communities identified with eDNA may also be used to track changes in sediments, similar to other biological proxies described earlier (e.g., diatoms, sub-fossil invertebrates). For example, Capo et al. (2019) examined annual variations in microbial community from a 40year sediment record to identify how the aquatic microbiota changed in response to climate. The authors found increases in the relative abundance of Chlorophyta, Dinophyceae, and Cyanobacteria (i.e., taxa correlated to increased phosphorus) during periods of warmer winter temperatures. By extension, similar methods may be used to track changes in avian numbers, which have a strong effect on nutrient concentrations of the aquatic and terrestrial environments.

\section{Bile Acids}

Bile acids are an additional emerging paleolimnological proxy, similar to lipid biomolecules, that can be used to track fecal inputs in sediments. Bile is originally produced within the liver of an organism and, when it reaches the intestines after a meal, is biotransformed by the metabolism of microorganisms (Ridlon et al., 2016). The bile acids are then released into the environment via excretion. As bile acid structures vary depending on the animal class (Bull et al., 2002; Hofmann et al., 2010), they may be used to track changes in avian colony size, with potentially a higher resolution for species identification than other lipid molecules or geochemistry.

\section{CONCLUSION}

Paleolimnological approaches can provide scientists with the long-term context needed to determine whether a population

\section{REFERENCES}

Adams, T. S., and Sterner, R. W. (2000). The effect of dietary nitrogen content on trophic level ${ }^{15} \mathrm{~N}$ enrichment. Limnol. Oceanogr. 45, 601-607. doi: 10.4319/lo. 2000.45.3.0601

Anderson, W. B., and Polis, G. A. (1999). Nutrient fluxes from water to land: seabirds affect plant nutrient status on Gulf of California islands. Oecologia 118, 324-332. doi: 10.1007/s004420050733

Appleby, P. G. (2001). “Chronostratigraphic techniques in recent sediments”, in Tracking Environmental Change Using Lake Sediments: Basin Analysis, Coring, and Chronological Techniques, eds W. M. Last and J. P. Smol (Dordrecht: Kluwer Academic Publishers), 171-204. is in decline or is within the natural range of variability. As a result, resources can be effectively allocated to protect a species with realistic management goals. In our review of 69 studies, we demonstrated the efficacy of sediment archives to add the critical temporal context needed to understand baseline conditions and natural variability of avian populations for the last 10,000 years. Ultimately, by combining paleoecological techniques with modern wildlife monitoring approaches, it will be possible to access temporal perspectives that are otherwise lost to time.

\section{DATA AVAILABILITY STATEMENT}

A comprehensive table of the studies examined in this review is provided in the Supplementary Material.

\section{AUTHOR CONTRIBUTIONS}

MPD conceived the idea for this review. All authors contributed text and revisions to the manuscript, and approved the final version.

\section{FUNDING}

This review was primarily supported by the Natural Sciences and Engineering Research Council of Canada via Discovery grants to the authors as well as a graduate fellowship to MPD.

\section{ACKNOWLEDGMENTS}

The art for Figures 1, 2 was created by Kara Perilli (https:// karaperilli.myportfolio.com/) and is reproduced here with her permission. Thank you to Steven Emslie for his comments on Figure 4.

\section{SUPPLEMENTARY MATERIAL}

The Supplementary Material for this article can be found online at: https://www.frontiersin.org/articles/10.3389/fevo.2021. 698175/full\#supplementary-material

Baroni, C., and Orombelli, G. (1994). Abandoned penguin rookeries as Holocene paleoclimatic indicators in Antarctica. Geology 22, 23-26. doi: 10.1130/009176131994022<0023:APRAHP<2.3.CO;2

Bartlett, P. D. (1987). Degradation of coprostanol in an experimental system. Mar. Pollut. Bull. 18, 27-29. doi: 10.1016/0025-326X(87)90653-9

Battarbee, R. W., Jones, V. J., Flower, R. J., Cameron, N. G., Bennion, H., Carvalho, L., et al. (2001). "Diatoms," in Tracking Environmental Change Using Lake Sediments: Terrestrial, Algal, and Siliceous Indicators, eds J. P. Smol, H. J. B. Birks, and W. M. Last (Dordrecht: Kluwer Academic Publishers), 155-202.

Bauer, S., and Hoye, B. J. (2014). Migratory animals couple biodiversity and ecosystem functioning worldwide. Science 344:1242552. doi: 10.1126/science. 1242552 
Benfenati, E., Cools, E., Fattore, E., and Fanelli, R. (1994). A GC-MS method for the analysis of fecal and plant sterols in sediment samples. Chemosphere 29, 1393-1405. doi: 10.1016/0045-6535(94)90273-9

Beresford, A. E., Sanderson, F. J., Donald, P. F., Burfield, I. J., Butler, A., Vickery, J. A., et al. (2019). Phenology and climate change in Africa and the decline of Afro-Palearctic migratory bird populations. Remote Sens. Ecol. Conserv. 5, 55-69. doi: 10.1002/rse2.89

Bicknell, A. W. J., Knight, M. E., Bilton, D., Reid, J. B., Burke, T., and Votier, S. C. (2012). Population genetic structure and long-distance dispersal among seabird populations: implications for colony persistence. Mol. Ecol. 21, 2863-2876. doi: 10.1111/j.1365-294X.2012.05558.x

BirdLife International (2017). Many albatross species are in alarming slow decline. Available online at: http://datazone.birdlife.org/sowb/casestudy/manyalbatross-species-are-in-alarming-slow-decline [Accessed March 17, 2021]

Birks, H. H. (2001). "Plant macrofossils," in Tracking Environmental Change Using Lake Sediments: Terrestrial, Algal, and Siliceous Indicators, eds J. P. Smol, H. J. B. Birks, and W. M. Last (Dordrecht: Kluwer Academic Publishers), 49-74.

Björck, S., and Wohlfarth, B. (2001). " ${ }^{14} \mathrm{C}$ chronostratigraphic techniques in paleolimnology," in Tracking Environmental Change Using Lake Sediments: Basin Analysis, Coring, and Chronological Techniques, eds W. M. Last and J. P. Smol (Dordrecht: Kluwer Academic Publishers), 205-245.

Blais, J. M., Macdonald, R. W., Mackay, D., Webster, E., Harvey, C., and Smol, J. P. (2007). Biologically mediated transport of contaminants to aquatic systems. Environ. Sci. Technol. 41, 1075-1084. doi: 10.1021/es061314a

Boës, X., Rydberg, J., Martinez-Cortizas, A., Bindler, R., and Renberg, I. (2011). Evaluation of conservative lithogenic elements ( $\mathrm{Ti}, \mathrm{Zr}, \mathrm{Al}$, and $\mathrm{Rb}$ ) to study anthropogenic element enrichments in lake sediments. J. Paleolimnol. 46, 75-87. doi: 10.1007/s10933-011-9515-z

Bonebrake, T. C., Christensen, J., Boggs, C. L., and Ehrlich, P. R. (2010). Population decline assessment, historical baselines, and conservation. Conserv. Lett. 3 , 371-378. doi: 10.1111/j.1755-263X.2010.00139.x

Boutin, C., Dobbie, T., Carpenter, D., and Hebert, C. E. (2011). Effects of double-crested cormorants (Phalacrocorax auritus Less.) on island vegetation, seedbank, and soil chemistry: evaluating island restoration potential. Restor. Ecol. 19, 720-727. doi: 10.1111/j.1526-100X.2010.00769.x

Bretscher, M. S. (1973). Membrane structure: some general principles. Science 181, 622-629. doi: 10.1126/science.181.4100.622

Brimble, S. K., Foster, K. L., Mallory, M. L., Macdonald, R. W., Smol, J. P., and Blais, J. M. (2009). High Arctic ponds receiving biotransported nutrients from a nearby seabird colony are also subject to potentially toxic loadings of arsenic, cadmium, and zinc. Environ. Toxicol. Chem. 28, 2426-2433. doi: 10.1897/09235.1

Brooks, S. J., Jones, V. J., Telford, R. J., Appleby, P. G., Watson, E., McGowan, S., et al. (2012). Population trends in the Slavonian grebe Podiceps auritus (L.) and Chironomidae (Diptera) at a Scottish loch. J. Paleolimnol. 47, 631-644. doi: 10.1007/s10933-012-9587-4

Bull, I. D., Lockheart, M. J., Elhmmali, M. M., Roberts, D. J., and Evershed, R. P. (2002). The origin of faeces by means of biomarker detection. Environ. Int. 27, 647-654. doi: 10.1016/s0160-4120(01)00124-6

Burnham, K. K., Burnham, W. A., and Newton, I. (2009). Gyrfalcon Falco rusticolus post-glacial colonization and extreme long-term use of nest-sites in Greenland. Ibis 151, 514-522. doi: 10.1111/j.1474-919X.2009.00939.x

Capo, E., Giguet-Covex, C., Rouillard, A., Nota, K., Heintzman, P. D., Vuillemin, A., et al. (2021). Lake sedimentary DNA research on past terrestrial and aquatic biodiversity: overview and recommendations. Quaternary 4:6. doi: 10.3390/ quat4010006

Capo, E., Rydberg, J., Tolu, J., Domaizon, I., Debroas, D., Bindler, R., et al. (2019). How does environmental inter-annual variability shape aquatic microbial communities? A 40-year annual record of sedimentary DNA from a boreal lake (Nylandssjön, Sweden). Front. Ecol. Evol. 7:245. doi: 10.3389/fevo.2019.00245

Chen, Q., Liu, X., Nie, Y., and Sun, L. (2013). Using visible reflectance spectroscopy to reconstruct historical changes in chlorophyll $a$ concentration in East Antarctic ponds. Polar Res. 32:19932. doi: 10.3402/polar.v32i0.19932

Chen, X., Wei, Y., Nie, Y., Wang, J., Emslie, S. D., and Liu, X. (2020a). Carbon isotopes of $n$-alkanoic acids in Antarctic ornithogenic sediments as indicators of sedimentary lipid sources and paleoecological change. Sci. Total Environ. 709:135926. doi: 10.1016/j.scitotenv.2019.135926
Chen, Y., Ge, J., Huang, T., Shen, L., Chu, Z., and Xie, Z. (2020b). Restriction of sulfate reduction on the bioavailability and toxicity of trace metals in Antarctic lake sediments. Mar. Pollut. Bull. 151:110807. doi: 10.1016/j.marpolbul.2019. 110807

Cheng, W., Kimpe, L. E., Mallory, M. L., Smol, J. P., and Blais, J. M. (2021). An ${ }^{1} 1100 \mathrm{yr}$ record of human and seabird occupation in the High Arctic inferred from pond sediments. Geology 49, 510-514. doi: 10.1130/G48215.1

Cheng, W., Sun, L., Kimpe, L. E., Mallory, M. L., Smol, J. P., Gallant, L. R., et al. (2016). Sterols and stanols preserved in pond sediments track seabird biovectors in a High Arctic environment. Environ. Sci. Technol. 50, 9351-9360. doi: 10.1021/acs.est.6b02767

Cifuentes, L. A., Fogel, M. L., Pennock, J. R., and Sharp, J. H. (1989). Biogeochemical factors that influence the stable nitrogen isotope ratio of dissolved ammonium in the Delaware Estuary. Geochim. Cosmochim. Acta 53, 2713-2721. doi: 10.1016/0016-7037(89)90142-7

Conroy, J. L., Collins, A. F., Overpeck, J. T., Bush, M. B., Cole, J. E., and Anderson, D. J. (2015). A 400-year isotopic record of seabird response to eastern tropical Pacific productivity. Geo: Geogr. Env. 2, 137-147. doi: 10.1002/geo2.11

Couture, R.-M., Shafei, B., Van Cappellen, P., Tessier, A., and Gobeil, C. (2010). Non-steady state modeling of arsenic diagenesis in lake sediments. Environ. Sci. Technol. 44, 197-203. doi: 10.1021/es902077q

Croll, D. A., Maron, J. L., Estes, J. A., Danner, E. M., and Byrd, G. V. (2005). Introduced predators transform subarctic islands from grassland to tundra. Science 307, 1959-1961. doi: 10.1126/science. 1108485

Danchin, E., and Wagner, R. H. (1997). The evolution of coloniality: the emergence of new perspectives. Trends Ecol. Evol. 12, 342-347. doi: 10.1016/S01695347(97)01124-5

D’Anjou, R. M., Bradley, R. S., Balascio, N. L., and Finkelstein, D. B. (2012). Climate impacts on human settlement and agricultural activities in northern Norway revealed through sediment biogeochemistry. Proc. Natl. Acad. Sci. U.S.A. 109, 20332-20337. doi: 10.1073/pnas.1212730109

Davidson, T. A., Wetterich, S., Johansen, K. L., Grønnow, B., Windirsch, T., Jeppesen, E., et al. (2018). The history of seabird colonies and the North Water ecosystem: Contributions from palaeoecological and archaeological evidence. Ambio 47, 175-192. doi: 10.1007/s13280-018-1031-1

Davis, O. K. (1987). Spores of the dung fungus Sporormiella: increased abundance in historic sediments and before Pleistocene megafaunal extinction. Quat. Res. 28, 290-294. doi: 10.1016/0033-5894(87)90067-6

De La Peña-Lastra, S. (2021). Seabird droppings: Effects on a global and local level. Sci. Total Environ. 754:142148. doi: 10.1016/j.scitotenv.2020.142148

Dietl, G. P., and Flessa, K. W. (2011). Conservation paleobiology: Putting the dead to work. Trends Ecol. Evol. 26, 30-37. doi: 10.1016/j.tree.2010.09.010

Dietl, G. P., Kidwell, S. M., Brenner, M., Burney, D. A., Flessa, K. W., Jackson, S. T., et al. (2015). Conservation paleobiology: Leveraging knowledge of the past to inform conservation and restoration. Annu. Rev. Earth Planet. Sci. 43, 79-103. doi: 10.1146/annurev-earth-040610-133349

Domaizon, I., Winegardner, A., Capo, E., Gauthier, J., and Gregory-Eaves, I. (2017). DNA-based methods in paleolimnology: New opportunities for investigating long-term dynamics of lacustrine biodiversity. J. Paleolimnol. 58, 1-21. doi: 10.1007/s10933-017-9958-y

Duda, M. P., Allen-Mahé, S., Barbraud, C., Blais, J. M., Boudreau, A., Bryant, R., et al. (2020a). Linking 19th century European settlement to the disruption of a seabird's natural population dynamics. Proc. Natl. Acad. Sci. U.S.A. 117, 32484-32492. doi: 10.1073/pnas.2016811117

Duda, M. P., Glew, J. R., Michelutti, N., Robertson, G. J., Montevecchi, W. A., Kissinger, J. A., et al. (2020b). Long-term changes in terrestrial vegetation linked to shifts in a colonial seabird population. Ecosystems 23, 1643-1656. doi: 10.1007/s10021-020-00494-8

Duda, M. P., Hargan, K. E., Michelutti, N., and Smol, J. P. (2019). Freshwater diatom assemblages from seabird-inhabited ponds in Hudson Strait, sub-Arctic Canada. Polar Biol. 42, 1549-1560. doi: 10.1007/s00300-019-02541-0

Duda, M. P., Robertson, G. J., Lim, J. E., Kissinger, J. A., Eickmeyer, D. C., Grooms, C., et al. (2020c). Striking centennial-scale changes in the population size of a threatened seabird. Proc. R. Soc. B 287:20192234. doi: 10.1098/rspb.2019. 2234

Emslie, S. D. (2021). Ancient Adélie penguin colony revealed by snowmelt at Cape Irizar. Ross Sea, Antarctica. Geol. 49, 145-149. doi: 10.1130/G48230.1 
Emslie, S. D., Baumann, K., and van Tuinen, M. (2011). Late Holocene occupation of Gentoo Penguins (Pygoscelis papua) on Byers Peninsula, Livingston Island, Antarctica. Polar Biol. 34, 283-290. doi: 10.1007/s00300-010-0886-9

Emslie, S. D., Coats, L., and Licht, K. (2007). A 45,000 yr record of Adélie penguins and climate change in the Ross Sea, Antartica. Geology 35, 61-64. doi: 10.1130/ G23011A.1

Emslie, S. D., and McDaniel, J. D. (2002). Adélie penguin diet and climate change during the middle to late Holocene in northern Marguerite Bay, Antarctic Peninsula. Polar Biol. 25, 222-229. doi: 10.1007/s00300-0010334-y

Emslie, S. D., McKenzie, A., and Patterson, W. P. (2018). The rise and fall of an ancient Adélie penguin 'supercolony' at Cape Adare, Antarctica. R. Soc. Open Sci. 5:172032. doi: 10.1098/rsos.172032

Emslie, S. D., Romero, M., Juáres, M. A., and Argota, M. R. (2020). Holocene occupation history of pygoscelid penguins at Stranger Point, King George (25 de Mayo) Island, northern Antarctic Peninsula. Holocene 30, 190-196. doi: $10.1177 / 0959683619875814$

Emslie, S. D., and Woehler, E. J. (2005). A 9000-year record of Adélie penguin occupation and diet in the Windmill Islands. East Antarctica. Antarctic Sci. 17, 57-66. doi: 10.1017/S0954102005002427

Esler, D. (2000). Applying metapopulation theory to conservation of migratory birds. Conserv. Biol. 14, 366-372. doi: 10.1046/j.1523-1739.2000.98147.x

Evenset, A., Carroll, J., Christensen, G. N., Kallenborn, R., Gregor, D., and Gabrielsen, G. W. (2007a). Seabird guano is an efficient conveyer of persistent organic pollutants (POPs) to Arctic lake ecosystems. Environ. Sci. Technol. 41, 1173-1179. doi: 10.1021/es0621142

Evenset, A., Christensen, G. N., Caroll, J., Zaborska, A., Berger, U., Herzke, D., et al. (2007b). Historical trends in persistent organic pollutants and metals recorded in sediment from Lake Ellasjøen, Bjørnøya, Norwegian Arctic. Environ. Pollut. 146, 196-205. doi: 10.1016/j.envpol.2006.04.038

Feng, S., Fang, Q., Barnett, R., Li, C., Han, S., Kuhlwilm, M., et al. (2019). The genomic footprints of the fall and recovery of the crested ibis. Curr. Biol. 29, 340-349. doi: 10.1016/j.cub.2018.12.008

Finney, B. P., Gregory-Eaves, I., Douglas, M. S. V., and Smol, J. P. (2002). Fisheries productivity in the northeastern Pacific Ocean over the past 2,200 years. Nature 416, 729-733. doi: 10.1038/416729a

Finney, B. P., Gregory-Eaves, I., Sweetman, J., Douglas, M. S. V., and Smol, J. P. (2000). Impacts of climatic change and fishing on pacific salmon abundance over the past 300 years. Science 290, 795-799. doi: 10.1126/science.290.5492.795

Förstner, U., Ahlf, W., and Calmano, W. (1993). Sediment quality objectives and criteria development in Germany. Water Sci. Technol. 28, 307-316. doi: 10. 2166/wst.1993.0629

Frishkoff, L. O., Karp, D. S., Flanders, J. R., Zook, J., Hadly, E. A., Daily, G. C., et al. (2016). Climate change and habitat conversion favour the same species. Ecol. Lett. 19, 1081-1090. doi: 10.1111/ele.12645

Froyd, C. A., and Willis, K. J. (2008). Emerging issues in biodiversity \& conservation management: the need for a palaeoecological perspective. Quat. Sci. Rev. 27, 1723-1732. doi: 10.1016/j.quascirev.2008.06.006

Gallant, L. R., Fenton, M. B., Grooms, C., Bogdanowicz, W., Stewart, R. S., Clare, E. L., et al. (2021). A 4,300-year history of dietary changes in a bat colony determined from a tropical guano deposit. J. Geophys. Res. - Biogeo. 126:e2020JG006026. doi: 10.1029/2020JG006026

Gallant, L. R., Grooms, C., Kimpe, L. E., Smol, J. P., Bogdanowicz, W., Stewart, R. S., et al. (2020). A bat guano deposit in Jamaica recorded agricultural changes and metal exposure over the last $>4300$ years. Palaeogeogr. Palaeoclimatol. Palaeoecol. 538:109470. doi: 10.1016/j.palaeo.2019.109470

Gao, Y., Yang, L., Wang, J., Xie, Z., Wang, Y., and Sun, L. (2018a). Penguin colonization following the last glacial-interglacial transition in the Vestfold Hills, East Antarctica. Palaeogeogr. Palaeoclimatol. Palaeoecol. 490, 629-639. doi: 10.1016/j.palaeo.2017.11.053

Gao, Y., Yang, L., Xie, Z., Emmerson, L., Southwell, C., Wang, Y., et al. (2018b). Last millennium Adélie penguin mortality and colony abandonment events on Long Peninsula, East Antarctica. J. Geophys. Res. - Biogeo. 123, 2878-2889. doi: 10.1029/2018JG004550

Gao, Y., Yang, L., Yang, W., Wang, Y., Xie, Z., and Sun, L. (2018c). Dynamics of penguin population size and food availability at Prydz Bay, East Antarctica, during the last millennium: A solar control. Palaeogeogr. Palaeoclimatol. Palaeoecol. 516, 220-231. doi: 10.1016/j.palaeo.2018.11.027
Giguet-Covex, C., Pansu, J., Arnaud, F., Rey, P.-J., Griggo, C., Gielly, L., et al. (2014). Long livestock farming history and human landscape shaping revealed by lake sediment DNA. Nat. Commun. 5:3211. doi: 10.1038/ncomms4211

Ginn, B. K., Rühland, K. M., Young, J. D., Hawryshyn, J., Quinlan, R., Dillon, P. J., et al. (2012). The perils of using sedimentary phosphorus concentrations for inferring long-term changes in lake nutrient levels: comments on Hiriart-Baer et al., 2011. J. Great Lakes Res. 38, 825-829. doi: 10.1016/j.jglr.2012.09.002

Glew, J. R., Smol, J. P., and Last, W. M. (2001). "Sediment core collection and extrusion," in Tracking Environmental Change Using Lake Sediments: Basin Analysis, Coring, and Chronological Techniques, eds W. M. Last and J. P. Smol (Dordrecht: Kluwer Academic Publishers), 73-105.

Góngora, E., Elliott, K. H., and Whyte, L. (2021). Gut microbiome is affected by inter-sexual and inter-seasonal variation in diet for thick-billed murres (Uria lomvia). Sci. Rep. 11:1200. doi: 10.1038/s41598-020-80557-x

Gregory-Eaves, I., Smol, J. P., Douglas, M. S. V., and Finney, B. P. (2003). Diatoms and sockeye salmon (Oncorhynchus nerka) population dynamics: Reconstructions of salmon-derived nutrients over the past 2,200 years in two lakes from Kodiak Island, Alaska. J. Paleolimnol. 30, 35-53. doi: 10.1023/A: 1024792831385

Griffiths, K., Michelutti, N., Blais, J. M., Kimpe, L. E., and Smol, J. P. (2010). Comparing nitrogen isotopic signals between bulk sediments and invertebrate remains in High Arctic seabird-influenced ponds. J. Paleolimnol. 44, 405-412. doi: 10.1007/s10933-009-9354-3

Groff, D. V., Hamley, K. M., Lessard, T. J. R., Greenawalt, K. E., Yasuhara, M., Brickle, P., et al. (2020). Seabird establishment during regional cooling drove a terrestrial ecosystem shift 5000 years ago. Sci. Adv. 6:eabb2788. doi: 10.1126/ sciadv.abb 2788

Hall, R. D., and Herhardt, R. R. (2002). “Flies (Diptera)," in Medical and Veterinary Entomology, eds G. Mullen and L. Durden (San Diego: Academic Press), 127-145.

Hargan, K. E., Gilchrist, H. G., Clyde, N. M. T., Iverson, S. A., Forbes, M. R., Kimpe, L. E., et al. (2019). Multicentury perspective assessing the sustainability of the historical harvest of seaducks. Proc. Natl. Acad. Sci. U.S.A. 116, 8425-8430. doi: 10.1073/pnas.1814057116

Hargan, K. E., Stewart, E. M., Michelutti, N., Grooms, C., Kimpe, L. E., Mallory, M. L., et al. (2018). Sterols and stanols as novel tracers of waterbird population dynamics in freshwater ponds. Proc. R. Soc. B 285:20180631. doi: $10.1098 / \mathrm{rspb}$. 2018.0631

Harrault, L., Milek, K., Jardé, E., Jeanneau, L., Derrien, M., and Anderson, D. G. (2019). Faecal biomarkers can distinguish specific mammalian species in modern and past environments. PLoS ONE 14:e0211119. doi: 10.1371/journal. pone.0211119

Hazen, E. L., Abrahms, B., Brodie, S., Carroll, G., Jacox, M. G., Savoca, M. S., et al. (2019). Marine top predators as climate and ecosystem sentinels. Front. Ecol. Environ. 17:565-574. doi: 10.1002/fee.2125

Hobson, K. A. (2021). Ontario's decision for the province-wide cull of doublecrested cormorants. Avian Conserv. Ecol. 16:24. doi: 10.5751/ACE-01949160124

Hofmann, A. F., Hagey, L. R., and Krasowski, M. D. (2010). Bile salts of vertebrates: Structural variation and possible evolutionary significance. J. Lipid Res. 51, 226-246. doi: 10.1194/jlr.R000042

Holmes, J. A. (2001). “Ostracoda," in Tracking Environmental Change Using Lake Sediments: Zoological Indicators, eds J. P. Smol, H. J. B. Birks, and W. M. Last (Dordrecht: Kluwer Academic Publishers), 125-151.

Holtgrieve, G. W., and Schindler, D. E. (2011). Marine-derived nutrients, bioturbation, and ecosystem metabolism: Reconsidering the role of salmon in streams. Ecology 92, 373-385. doi: 10.1890/09-1694.1

Honda, K., Marcovecchio, J. E., Kan, S., Tatsukawa, R., and Ogi, H. (1990). Metal concentrations in pelagic seabirds from the North Pacific Ocean. Arch. Environ. Contam. Toxicol. 19, 704-711. doi: 10.1007/BF01183988

Hu, Q.-H., Sun, L.-G., Xie, Z.-Q., Emslie, S. D., and Liu, X. D. (2013). Increase in penguin populations during the Little Ice Age in the Ross Sea, Antarctica. Sci. Rep. 3:2472. doi: $10.1038 /$ srep02472

Huang, J., Sun, L., Huang, W., Wang, X., and Wang, Y. (2010). The ecosystem evolution of penguin colonies in the past 8,500 years on Vestfold Hills, East Antarctica. Polar Biol. 33, 1399-1406. doi: 10.1007/s00300-010-0832-x

Huang, T., Sun, L., Wang, Y., Chu, Z., Qin, X., and Yang, L. (2014). Transport of nutrients and contaminants from ocean to island by emperor penguins 
from Amanda Bay, East Antarctic. Sci. Total Environ. 468-469, 578-583. doi: 10.1016/j.scitotenv.2013.08.082

Huang, T., Sun, L., Wang, Y., and Kong, D. (2011). Late Holocene Adélie penguin population dynamics at Zolotov Island, Vestfold Hills, Antarctica. J. Paleolimnol. 45, 273-285. doi: 10.1007/s10933-011-9497-X

Huang, T., Sun, L., Wang, Y., Liu, X., and Zhu, R. (2009a). Penguin population dynamics for the past 8500 years at Gardner Island, Vestfold Hills. Antarctic Sci. 21, 571-578. doi: 10.1017/S0954102009990332

Huang, T., Sun, L., Wang, Y., and Zhu, R. (2009b). Penguin occupation in the Vestfold Hills. Antarctic Sci. 21, 131-134. doi: 10.1017/S09541020080 0165X

Huang, T., Yang, L., Chu, Z., Sun, L., and Yin, X. (2016). Geochemical record of high emperor penguin populations during the Little Ice Age at Amanda Bay, Antarctica. Sci. Total Environ. 565, 1185-1191. doi: 10.1016/j.scitotenv.2016. 05.166

Hughes, B. B., Beas-Luna, R., Barner, A. K., Brewitt, K., Brumbaugh, D. R., CernyChipman, E. B., et al. (2017). Long-term studies contribute disproportionately to ecology and policy. BioScience 67, 271-281. doi: 10.1093/biosci/ biw 185

Hung, C.-M., Shaner, P.-J. L., Zink, R. M., Liu, W.-C., Chu, T.-C., Huang, W.S., et al. (2014). Drastic population fluctuations explain the rapid extinction of the passenger pigeon. Proc. Natl. Acad. Sci. U.S.A. 111, 10636-10641. doi: $10.1073 /$ pnas.1401526111

Inger, R., Gregory, R., Duffy, J. P., Stott, I., Voříšek, P., and Gaston, K. J. (2014). Common European birds are declining rapidly while less abundant species' numbers are rising. Ecol. Lett. 18, 28-36. doi: 10.1111/ele.12387

Johnson, J. H., Farquhar, J. F., Klindt, R. M., Mazzocchi, I., and Mathers, A. (2015). From yellow perch to round goby: A review of double-crested cormorant diet and fish consumption at three St. Lawrence River colonies, 1999-2013. J. Great Lakes Res. 41, 259-265. doi: 10.1016/j.jglr.2014.12.011

Johnson, J. H., Ross, R. M., McCullough, R. D., and Mathers, A. (2010). Diet shift of double-crested cormorants in eastern Lake Ontario associated with the expansion of the invasive round goby. J. Great Lakes Res. 36, 242-247. doi: $10.1016 /$ j.jglr.2010.02.013

Jones, C. G., Lawton, J. H., and Shachak, M. (1994). Organisms as ecosystem engineers. Oikos 69, 373-386. doi: 10.2307/3545850

Keatley, B. E., Blais, J. M., Douglas, M. S. V., Gregory-Eaves, I., Mallory, M. L., Michelutti, N., et al. (2011). Historical seabird population dynamics and their effects on Arctic pond ecosystems: A multi-proxy paleolimnological study from Cape Vera, Devon Island, Arctic Canada. Fundam. Appl. Limnol. 179, 51-66. doi: 10.1127/1863-9135/2011/0179-0051

Keeling, C. D. (1979). The Suess effect: ${ }^{13}$ carbon- ${ }^{14}$ carbon interrelations. Environ. Int. 2, 229-300. doi: 10.1016/0160-4120(79)90005-9

Kersten, M., and Smedes, F. (2002). Normalization procedures for sediment contaminants in spatial and temporal trend monitoring. J. Environ. Monit. 4, 109-115. doi: 10.1039/B108102K

Korosi, J. B., Cheng, W., and Blais, J. M. (2015). “Organic pollutants in sediment core archives," in Developments in Paleoenvironmental Research: Environmental Contaminants. Using Natural Archives to Track Sources and Long-term Trends of Pollution, eds J. M. Blais, M. R. Rosen, and J. P. Smol (Dordrecht: Springer), 161-186.

Koski-Vähälä, J., Hartikainen, H., and Tallberg, P. (2001). Phosphorus mobilization from various sediment pools in response to increased $\mathrm{pH}$ and silicate concentration. J. Environ. Qual. 30, 546-552. doi: 10.2134/jeq2001.302546x

Kouassi, N. L. B., Yao, K. M., Sangare, N., Trokourey, A., and Metongo, B. S. (2019). The mobility of the trace metals copper, zinc, lead, cobalt, and nickel in tropical estuarine sediments, Ebrie Lagoon, Côte d'Ivoire. J. Soil. Sediment. 19, 929-944. doi: 10.1007/s11368-018-2062-8

Kuussaari, M., Bommarco, R., Heikkinen, R. K., Helm, A., Krauss, J., and Lindborg, R. (2009). Extinction debt: A challenge for biodiversity conservation. Trends Ecol. Evol. 24, 564-571. doi: 10.1016/j.tree.2009.04.011

Leavitt, P. R., and Hodgson, D. C. (2001). "Sedimentary pigments," in Tracking Environmental Change Using Lake Sediments: Terrestrial, Algal, and Siliceous Indicators, eds J. P. Smol, H. J. B. Birks, and W. M. Last (Dordrecht: Kluwer Academic Publishers), 295-325.

Leeming, R., Ball, A., Ashbolt, N., and Nichols, P. (1996). Using faecal sterols from humans and animals to distinguish faecal pollution in receiving waters. Water Res. 30, 2893-2900. doi: 10.1016/S0043-1354(96)00011-5
Leng, M. J. (2006). Isotopes in Palaeoenvironmental Research. Dordrecht: Springer, doi: 10.1007/1-4020-2504-1

Li, C., Zhang, Y., Li, J., Kong, L., Hu, H., Pan, H., et al. (2014). Two Antarctic penguin genomes reveal insights into their evolutionary history and molecular changes related to the Antarctic environment. GigaScience 3:27. doi: 10.1186/ 2047-217X-3-27

Lim, J. E., Duda, M. P., and Smol, J. P. (2021). Chironomid assemblage changes and chitin degradation in response to 1700 -years of seabird population fluctuations at the world's largest colony of Leach's storm-petrels (Atlantic Canada). J. Paleolimnol. 65, 429-433. doi: 10.1007/s10933-021-00181-1

Liu, K.-K., Chao, S.-Y., Shaw, P.-T., Gong, G.-C., Chen, C.-C., and Tang, T. Y. (2002). Monsoon-forced chlorophyll distribution and primary production in the South China Sea: observations and a numerical study. Deep Sea Res. 1, 1387-1412. doi: 10.1016/S0967-0637(02)00035-3

Liu, X., Nie, Y., Sun, L., and Emslie, S. D. (2013). Eco-environmental implications of elemental and carbon isotope distributions in ornithogenic sediments from the Ross Sea region, Antarctica. Geochim. Cosmochim. Acta 117, 99-114. doi: 10.1016/j.gca.2013.04.013

Liu, X., Sun, J., Sun, L., Liu, W., and Wang, Y. (2011). Reflectance spectroscopy: A new approach for reconstructing penguin population size from Antarctic ornithogenic sediments. J. Paleolimnol. 45, 213-222. doi: 10.1007/s10933-0109493-6

Liu, X., Sun, L., Xie, Z., Yin, X., and Wang, Y. (2005). A 1300-year record of penguin populations at Ardley Island in the Antarctic, as deduced from the geochemical data in the ornithogenic lake sediments. Arct. Antarct. Alp. Res. 37, 490-498. doi: 10.1657/1523-04302005037[0490:AYROPP]2.0.CO;2

Liu, X., Sun, L., Xie, Z., Yin, X., Zhu, R., and Wang, Y. (2007). A preliminary record of the historical seabird population in the Larsemann Hills, East Antarctica, from geochemical analyses of Mochou Lake sediments. Boreas 36, 182-197. doi: 10.1080/03009480600991789

Liu, X., Zhao, S., Sun, L., Yin, X., Xie, Z., Honghao, L., et al. (2006a). P and trace metal contents in biomaterials, soils, sediments and plants in colony of red-footed booby (Sula sula) in the Dongdao Island of South China Sea. Chemosphere 65, 707-715. doi: 10.1016/j.chemosphere.2006.01.043

Liu, X.-D., Li, H.-C., Sun, L.-G., Yin, X.-B., Zhao, S.-P., and Wang, Y.-H. (2006b). $\delta^{13} \mathrm{C}$ and $\delta^{15} \mathrm{~N}$ in the ornithogenic sediments from the Antarctic maritime as palaeoecological proxies during the past 2000 yr. Earth Planet. Sci. Lett. 243, 424-438. doi: 10.1016/j.epsl.2006.01.018

Liu, X. D., Zhao, S. P., Sun, L. G., Luo, H. H., Yin, Z. B., Xie, Y. H., et al. (2006c). Geochemical evidence for the variation of historical seabird population on Dongdao Island of the South China Sea. J. Paleolimnol. 36, 259-279. doi: 10.1007/s10933-006-9006-9

Lock, J. W., Thompson, D. R., Furness, R. W., and Bartle, J. A. (1992). Metal concentrations in seabirds of the New Zealand region. Environ. Pollut. 75, 289-300. doi: 10.1016/0269-7491(92)90129-X

Loring, D. (1991). Normalization of heavy-metal data from estuarine and coastal sediments. J. Mar. Sci. 48, 101-115. doi: 10.1093/icesjms/48.1.101

Lotze, H. K., and Worm, B. (2009). Historical baselines for large marine animals. Trends Ecol. Evol. 24, 254-262. doi: 10.1016/j.tree.2008.12.004

Luoto, T. P., Brooks, S. J., and Salonen, V.-P. (2014). Ecological responses to climate change in a bird-impacted High Arctic pond (Nordaustlandet, Svalbard). J. Paleolimnol. 51, 87-97. doi: 10.1007/s10933-013-9757-z

Luoto, T. P., Oksman, M., and Ojala, A. E. K. (2015). Climate change and bird impact as drivers of High Arctic pond deterioration. Polar Biol. 38, 357-368. doi: 10.1007/s00300-014-1592-9

Luoto, T. P., Rantala, M. V., Kivilä, E. H., Nevalainen, L., and Ojala, A. E. K. (2019). Biogeochemical cycling and ecological thresholds in a High Arctic lake (Svalbard). Aquat. Sci. 81:34. doi: 10.1007/s00027-019-0630-7

MacDonald, L. A., Farquharson, N., Merritt, G., Fooks, S., Medeiros, A. S., Hall, R. I., et al. (2015). Limnological regime shifts caused by climate warming and Lesser Snow Goose population expansion in the western Hudson Bay Lowlands (Manitoba, Canada). Ecol Evol. 5, 921-939. doi: 10.1002/ece3.1354

Madura, P. T., and Jones, H. P. (2016). Invasive species sustain double-crested cormorants in southern Lake Michigan. J. Great Lakes Res. 42, 413-420. doi: 10.1016/j.jglr.2015.12.009

Mallory, M. L., and Braune, B. M. (2012). Tracking contaminants in seabirds of Arctic Canada: Temporal and spatial insights. Mar. Pollut. Bull. 64, 1475-1484. doi: 10.1016/j.marpolbul.2012.05.012 
Mason, L. R., Green, R. E., Howard, C., Stephens, P. A., Willis, S. G., Aunins, A., et al. (2019). Population responses of bird populations to climate change on two continents vary with species' ecological traits but not with direction of change in climate suitability. Clim. Change 157, 337-354. doi: 10.1007/s10584019-02549-9

Merkel, F. R. (2004). Evidence of population decline in common eiders breeding in Western Greenland. Arctic 57, 27-36. doi: 10.14430/arctic480

Michelutti, N., Blais, J. M., Cumming, B. F., Paterson, A. M., Rühland, K., Wolfe, A. P., et al. (2010a). Do spectrally inferred determinations of chlorophyll $a$ reflect trends in lake trophic status? J. Paleolimnol. 43, 205-217. doi: 10.1007/ s10933-009-9325-8

Michelutti, N., Blais, J. M., Mallory, M. L., Brash, J., Thienpont, J., Kimpe, L. E., et al. (2010b). Trophic position influences the efficacy of seabirds as metal biovectors. Proc. Natl. Acad. Sci. U.S.A. 107, 10543-10548. doi: 10.1073/pnas.100133 3107

Michelutti, N., Keatley, B. E., Brimble, S., Blais, J. M., Liu, H., Douglas, M. S. V., et al. (2009). Seabird-driven shifts in Arctic pond ecosystems. Proc. R. Soc. B 276, 591-596. doi: 10.1098/rspb.2008.1103

Michelutti, N., Mallory, M. L., Blais, J. M., Douglas, M. S. V., and Smol, J. P. (2011). Chironomid assemblages from seabird-affected High Arctic ponds. Polar Biol. 34, 799-812. doi: 10.1007/s00300-010-0934-5

Michelutti, N., and Smol, J. P. (2016). Visible spectroscopy reliably tracks trends in paleo-production. J. Paleolimnol. 56, 253-265. doi: 10.1007/s10933-016-99213

Miller, E. K., Blum, J. D., and Friedland, A. J. (1993). Determination of soil exchangeable-cation loss and weathering rates using Sr isotope. Nature 362, 438-441. doi: 10.1038/362438a0

Minagawa, M., and Wada, E. (1984). Stepwise enrichment of ${ }^{15} \mathrm{~N}$ along food chains: Further evidence and the relation between $\delta^{15} \mathrm{~N}$ and animal age. Geochim. Cosmochim. Acta 48, 1135-1140. doi: 10.1016/0016-7037(84)90204-7

Müller, G. (1979). Schwermetalle in den Sedimenten des Rheins - Verlinderungen seit 1971. Umsch. Wiss. Tech. 79, 778-783.

Navarro, L., Harvey, A. -É, and Morin, H. (2017). Lepidoptera wing scales: A new paleoecological indicator for reconstructing spruce budworm abundance. Can. J. For. Res. 48, 302-308. doi: 10.1139/cjfr-2017-0009

Nie, Y., Liu, X., and Emslie, S. D. (2014a). Distribution and sources of rare earth elements in ornithogenic sediments from the Ross Sea region, Antarctica. Microchem. J. 114, 247-260. doi: 10.1016/j.microc.2014. 01.010

Nie, Y., Liu, X., Wen, T., Sun, L., and Emslie, S. D. (2014b). Environmental implication of nitrogen isotopic composition in ornithogenic sediments from the Ross Sea region, East Antarctica: $\Delta^{15} \mathrm{~N}$ as a new proxy for avian influence. Chem. Geol. 363, 91-100. doi: 10.1016/j.chemgeo.2013.10.031

Nie, Y., Sun, L., Liu, X., and Emslie, S. D. (2015). From warm to cold: Migration of Adélie penguins within Cape Bird, Ross Island. Sci. Rep. 5:11530. doi: 10.1038/ srep 11530

Nocera, J. J., Blais, J. M., Beresford, D. V., Finity, L. K., Grooms, C., Kimpe, L. E., et al. (2012). Historical pesticide applications coincided with an altered diet of aerially foraging insectivorous chimney swifts. Proc. R. Soc. B 279, 3114-3120. doi: $10.1098 /$ rspb. 2012.0445

Otero, X. L., De La Peña-Lastra, S., Pérez-Alberti, A., Ferreira, T. O., and HeurtaDiaz, M. A. (2018). Seabird colonies as important global drivers in the nitrogen and phosphorus cycles. Nat. Comm. 9:246. doi: 10.1038/s41467-017-02446-8

Outridge, P. M., Goodsite, M. E., Bennike, O., Rausch, N., and Shotyk, W. (2016). Seabird transfer of nutrients and trace elements from the North Water Polynya to land during the Mid-Holocene warm period, Carey Islands, Northwest Greenland. Arctic 69, 253-265. doi: 10.14430/arctic4577

Paleczny, M., Hammill, E., Karpouzi, V., and Pauly, D. (2015). Population trend of the world's monitored seabirds, 1950-2010. PLoS One 10:e129342. doi: 10. 1371/journal.pone.0129342

Parsons, M., Mitchell, I., Butler, A., Ratcliffe, N., Frederiksen, M., Foster, S., et al. (2008). Seabirds as indicators of the marine environment. ICES J. Mar. Sci. 65, 1520-1526. doi: 10.1093/icesjms/fsn155

Paterson, I. G., and Snyder, M. (1999). Molecular genetic (RAPD) analysis of Leach's storm-petrels. Auk 116, 338-344. doi: 10.2307/4089368

Pollet, I. L., Bond, A. L., Hedd, A., Huntington, C. E., Butler, R. G., and Mauck, R. (2020). "Leach's Storm-Petrel (Oceanodroma leucorhoa)," in Birds of the World, eds S. M. Billerman, B. K. Keeney, P. G. Rodewald, and T. S. Schulenberg (Ithaca: Cornell Lab of Ornithology), doi: 10.2173/bow.lcspet.01

Quinlan, R., and Smol, J. P. (2001). Setting minimum head capsule abundance and taxa deletion criteria in chironomid-based inference models. J. Paleolimnol. 26, 327-342. doi: 10.1023/A:1017546821591

Reeves, A. S., and Patton, D. (2001). Measuring change in sterol input to estuarine sediments. Phys. Chem. Earth B 26, 753-757. doi: 10.1016/S1464-1909(01) 00081-8

Ribeiro, S., Limoges, A., Massé, G., Johansen, K. L., Colgan, W., Weckström, K., et al. (2021). Vulnerability of the North Water ecosystem to climate change. Nat. Comm. 12:4475. doi: 10.1038/s41467-021-24742-0

Ridlon, J. M., Harris, S. C., Bhowmik, S., Kang, D.-J., and Hylemon, P. B. (2016). Consequences of bile salt biotransformations by intestinal bacteria. Gut Microbes 7, 22-39. doi: 10.1080/19490976.2015.1127483

Roberts, S. J., Monien, P., Foster, L. C., Loftfield, J., Hocking, E. P., Schnetger, B., et al. (2017). Past penguin colony responses to explosive volcanism on the Antarctic Peninsula. Nat. Comm. 8:14914. doi: 10.1038/ncomms 14914

Rosenberg, K. V., Dokter, A. M., Blancher, P. J., Sauer, J. R., Smith, A. C., Smith, P. A., et al. (2019). Decline of the North American avifauna. Science 366, 120-124. doi: 10.1126/science.aaw1313

Saba, G. K., Fraser, W. R., Saba, V. S., Iannuzzi, R. A., Coleman, K. E., Doney, S. C., et al. (2014). Winter and spring controls on the summer food web of the coastal West Antarctic Peninsula. Nat. Comm. 5:4318. doi: 10.1038/ncomms 5318

Sánchez-Zapata, J. A., Donázar, J. A., Delgado, A., Forero, M. G., Ceballos, O., and Hiraldo, F. (2007). Desert locust outbreaks in the Sahel: resource competition, predation and ecological effects of pest control. J. Appl. Ecol. 44, 323-329. doi: 10.1111/j.1365-2664.2007.01279.x

Savage, C., Leavitt, P. R., and Elmgren, R. (2004). Distribution and retention of effluent nitrogen in surface sediments of a coastal bay. Limnol. Oceanogr. 49, 1503-1511. doi: 10.4319/lo.2004.49.5.1503

Schelske, C. L., and Hodell, D. A. (1995). Using carbon isotopes of bulk sedimentary organic matter to reconstruct the history of nutrient loading and eutrophication in Lake Erie. Limnol. Oceanogr. 40, 918-929. doi: 10.4319/lo.1995.40.5. 0918

Schroeter, N., Lauterbach, S., Stebich, M., Kalanke, J., Mingram, J., Yildiz, C., et al. (2020). Biomolecular evidence of early human occupation of a highaltitude site in Western Central Asia during the Holocene. Front. Earth Sci. 8:20. doi: 10.3389/feart.2020.00020

Seddon, A. W. R., Mackay, A. W., Baker, A. G., Birks, H. J. B., Breman, E., Buck, C. E., et al. (2014). Looking forward through the past: Identification of 50 priority research questions in palaeoecology. J. Ecol. 102, 256-267. doi: 10.1111/1365-2745.12195

Şekercioǧlu, ÇH., Daily, G. C., and Ehrlich, P. R. (2004). Ecosystem consequences of bird declines. Proc. Natl. Acad. Sci. U.S.A. 101, 18042-18047. doi: 10.1073/ pnas.0408049101

Selbie, D. T., Lewis, B. A., Smol, J. P., and Finney, B. P. (2007). Long-term population dynamics of the endangered Snake River sockeye salmon: Evidence of past influences on stock decline and impediments to recovery. Trans. Am. Fish. Soc. 136, 800-821. doi: 10.1577/t06-100.1

Shiozaki, T., and Chen, Y.-1.L (2013). Different mechanisms controlling interannual phytoplankton variation in the South China Sea and the western North Pacific subtropical gyre: A satellite study. Adv. Space Res. 52, 668-676. doi: 10.1016/j.asr.2013.05.005

Sinigalliano, C. D., Ervin, J. S., Van De Werfhorst, L., Badgley, B. D., Ballesté, E., Bartkowiak, J., et al. (2013). Multi-laboratory evaluations of the performance of Catellicoccus marimammalium PCR assays developed to target gull fecal sources. Water Res. 47, 6883-6896. doi: 10.1016/j.watres.2013. 02.059

Sklepkovych, B. O., and Montevecchi, W. A. (1989). The world's largest known nesting colony of Leach's storm-petrels on Baccalieu Island, Newfoundland. Am. Birds 43, 38-42.

Smol, J. P. (2008). Pollution of Lakes and Rivers: A Paleoenvironmetal Perspective. Oxford: Blackwell Publishing.

Smol, J. P., and Stoermer, E. F. (eds) (2010). The Diatoms: Applications for the Environmental and Earth Sciences. Cambridge: Cambridge University Press. 
Soga, M., and Gaston, K. J. (2018). Shifting baseline syndrome: Causes, consequences, and implications. Front. Ecol. Environ. 16:222-230. doi: 10.1002/ fee. 1794

Stewart, E. M., Hargan, K. E., Michelutti, N., Kimpe, L. E., Blais, J. M., and Smol, J. P. (2020). The impacts of waterbird-mediated elemental enrichment on chironomid assemblages from island ponds in Lake Ontario. Fundam. Appl. Limnol. 194, 107-124. doi: 10.1127/fal/2020/1328

Stewart, E. M., Michelutti, N., Shenstone-Harris, S., Grooms, C., Weseloh, C., Kimpe, L. E., et al. (2015). Tracking the history and ecological changes of rising double-crested cormorant populations using pond sediments from islands in Eastern Lake Ontario. PLoS One 10:e0134167. doi: 10.1371/journal.pone. 0134167

Stewart, E. M., Vu, M., Michelutti, N., Hargan, K., Grooms, C., Kimpe, L. E., et al. (2019). Pond sediments on nesting islands in eastern Lake Ontario provide insights into the population dynamics and impacts of waterbird colonies. J. Great Lakes Res. 45, 350-359. doi: 10.1016/j.jglr.2019.01.009

Sun, L., Xie, Z., and Zhao, J. (2000). A 3,000-year record of penguin populations. Nature 407:858. doi: 10.1038/35038163

Sun, L., Zhu, R., Liu, X., Xie, Z., Yin, X., Zhao, S., et al. (2005). HCl-soluble ${ }^{87} \mathrm{Sr} /{ }^{86} \mathrm{Sr}$ ratio in sediments impacted by penguin or seal excreta as a proxy for historical population size in the maritime Antarctic. Mar. Ecol. Prog. Ser. 303, 43-50. doi: $10.3354 /$ meps 303043

Sun, L., Zhu, R., Yin, X., Liu, X., Xie, Z., and Wang, Y. (2004). A geochemical method for the reconstruction of the occupation history of a penguin colony in the maritime Antarctic. Polar Biol. 27, 670-678. doi: 10.1007/s00300-004$0635-\mathrm{z}$

Sun, L. G., Emslie, S. D., Huang, T., Blais, J. M., Xie, Z. Q., Liu, X. D., et al. (2013). Vertebrate records in polar sediments: Biological responses to past climate change and human activities. Earth-Sci. Rev. 126, 147-155. doi: 10.1016/ j.earscirev.2013.08.004

Torres, I. C., Inglett, P. W., Brenner, M., Kenney, W. F., and Reddy, K. R. (2012). Stable isotope $\left(\delta^{13} \mathrm{C}\right.$ and $\left.\delta^{15} \mathrm{~N}\right)$ values of sediment organic matter in subtropical lakes of different trophic status. J. Paleolimnol. 47, 693-706. doi: 10.1007/ s10933-012-9593-6

Vanderploeg, H. A., Liebig, J. R., Carmichael, W. W., Agy, M. A., Johengen, T. H., Fahnenstiel, G. L., et al. (2001). Zebra mussel (Dreissena polymorpha) selective filtration promoted toxic Microcystis blooms in Saginaw Bay (Lake Huron) and Lake Erie. Can. J. Fish. Aquat. Sci. 58, 1208-1221. doi: 10.1139/cjfas-58-6- 1208

Velarde, E., Anderson, D. W., and Ezcurra, E. (2019). Seabird monitoring provides essential information on the state of marine ecosystems. Science 365, 116-117. doi: 10.1126/science.aaw9999

Walker, I. R. (2001). "Midges: Chironomidae and related Diptera," in Tracking Environmental Change Using Lake Sediments: Zoological Indicators, eds J. P. Smol, H. J. B. Birks, and W. M. Last (Dordrecht: Kluwer Academic Publishers), 43-66.

Wang, J., Wang, Y., Wang, X., and Sun, L. (2007). Penguins and vegetations on Ardley Island, Antarctica: Evolution in the past 2,400 years. Polar Biol. 30, 1475-1481. doi: 10.1007/s00300-007-0308-9

Wang, Z., Wang, Y., Zhao, P., Chen, L., Yan, C., Yan, Y., et al. (2015). Metal release from contaminated coastal sediments under changing $\mathrm{pH}$ conditions: Implications for metal mobilization in acidified oceans. Mar. Pollut. Bull. 101, 707-715. doi: 10.1016/j.marpolbul.2015.10.026

Wasiłowska, A., Tatur, A., Pushina, Z., Barczuk, A., and Verkulich, S. (2017). Impact of the 'Little Ice Age' climate cooling on the maar lake ecosystem affected by penguins: A lacustrine sediment record. Penguin Island, West Antarctica. Holocene 27, 1115-1131. doi: 10.1177/0959683616683254

Weseloh, D. V. C., Cuthbert, F. J., and King, D. T. (2012). Introduction: Doublecrested cormorants of the Great Lakes - St. Lawrence River Basin: Recent studies, movements and responses to management actions. Waterbirds 35, 1-3. doi: 10.1675/063.035.sp101

Wilhelm, S. I., Hedd, A., Robertson, G. J., Mailhiot, J., Regular, P. M., Ryan, P. C., et al. (2020). The world's largest breeding colony of Leach's storm-petrel Hydrobates leucorhous has declined. Bird Conserv. Int. 30, 40-57. doi: 10.1017/ S0959270919000248

Willis, K. J., and Birks, H. J. B. (2006). What is natural? The need for a longterm perspective in biodiversity conservation. Science 314, 1261-1265. doi: $10.1126 /$ science. 1122667
Wires, L. R., and Cuthbert, F. J. (2006). Historic populations of the doublecrested cormorant (Phalacrocorax auritus): Implications for conservation and management in the $21^{\text {st }}$ century. Waterbirds 29, 9-37. doi: 10.1675/15244695200629[9:HPOTDC]2.0.CO;2

Witmer, G. W. (2005). Wildlife population monitoring: Some practical considerations. Wildl. Res. 32, 259-263. doi: 10.1071/WR04003

Wood, J. R., and De Pietri, V. L. (2015). Next-generation paleornithology: Technological and methodological advances allow new insights into the evolutionary and ecological histories of living birds. Auk 132, 486-506. doi: 10.1642/AUK-14-257.1

Wood, J. R., Wilmshurst, J. M., Worthy, T. H., and Cooper, A. (2011). Sporormiella as a proxy for non-mammalian herbivores in island ecosystems. Quat. Sci. Rev. 30, 915-920. doi: 10.1016/j.quascirev.2011.01.007

Wooller, R. D., Bradley, J. S., and Croxall, J. P. (1992). Long-term population studies of seabirds. Trends Ecol. Evol. 7, 111-114. doi: 10.1016/0169-5347(92) 90143-Y

Wu, L., Liu, X., Fu, P., Xu, L., Li, D., and Li, Y. (2017a). Dietary change in seabirds on Guangjin Island, South China Sea, over the past 1200 years inferred from stable isotope analysis. Holocene 27, 331-338. doi: 10.1177/095968361666 0163

$\mathrm{Wu}, \mathrm{L}$., Liu, X., and Xu, L. (2017b). Change of organic $\delta^{13} \mathrm{C}$ in ornithogenic sediments of the Xisha Archipelago, South China Sea and its implication for ecological development. Acta Geol. Sin. - Engl. 91, 1109-1119. doi: 10.1111/ 1755-6724.13327

Wu, L., Liu, X., Xu, L., Fu, P., Wang, X., Jin, J., et al. (2018). Paleoecology of seabirds at Nandao, Xisha Islands, South China Sea: sub-fossil evidence for Ashmole's Halo during the Little Ice Age. Palaeogeogr. Palaeoclimatol. Palaeoecol. 505, $33-41$.

Xu, L., Liu, X., Wu, L., Sun, L., Zhao, J., and Chen, L. (2016). Decline of recent seabirds inferred from a composite 1000-year record of population dynamics. Sci. Rep. 6:35191. doi: 10.1038/srep35191

Xu, L.-Q., Liu, X.-D., Sun, L.-G., and Liu, W.-Q. (2012). Rapid identification of source material levels in coral sand ornithogenic sediments by reflectance spectroscopy. Ecol. Indic. 23, 517-523. doi: 10.1016/j.ecolind.2012. 05.004

Xu, L.-Q., Liu, X.-D., Sun, L.-G., Yan, H., Liu, Y., Luo, Y.-H., et al. (2011). Geochemical evidence for the development of coral island ecosystem in the Xisha Archipelago of South China Sea from four ornithogenic sediment profiles. Chem. Geol. 286, 135-145. doi: 10.1016/j.chemgeo.2011. 04.015

Xu, L. Q., Wu, L. B., Zhang, Y. H., and Zhao, J. J. (2019). Transport of cobalt and silver from the ocean to a reef island by seabirds in the South China Sea. J. Geophys. Res. - Biogeo. 124, 3005-3014. doi: 10.1029/2019JG00 5264

Xu, Q. B., Gao, Y. S., Yang, L. J., Yang, W. Q., Chu, Z. D., Wang, Y. H., et al. (2020). Abandonment of penguin subcolonies in the late nineteenth century on Inexpressible Island, Antarctica. J. Geophys. Res. - Biogeo 125:e2020JG006080. doi: 10.1029/2020JG006080

Yang, L., Gao, Y., Sun, L., Xie, Z., Yang, W., Chu, Z., et al. (2019). Enhanced westerlies drove penguin movement at $1000 \mathrm{yr}$ BP on Ardley Island, west Antarctic Peninsula. Quat. Sci. Rev. 214, 44-53. doi: 10.1016/j.quascirev.2019. 04.026

Yang, L., Gao, Y., Xu, Q., Huang, T., Yang, W., Chu, et al. (2021). Specific occupation of penguins under Neoglacial cooling on the Scott Coast, Antarctica. Quat. Sci. Rev. 264:107010. doi: 10.1016/j.quascirev.2021.107010

Yang, L., Sun, L., Emslie, S. D., Xie, Z., Huang, T., Gao, Y., et al. (2018). Oceanographic mechanisms and penguin population increases during the Little Ice Age in the southern Ross Sea, Antarctica. Earth Planet. Sci. Lett. 481, 136-142. doi: 10.1016/j.epsl.2017.10.027

Yuan, L., Sun, L., Long, N., Xie, Z., Wang, Y., and Liu, X. (2010). Seabirds colonized Ny-Ålesund, Svalbard, Arctic ₹9,400 years ago. Polar Biol. 33, 683-691. doi: 10.1007/s00300-009-0745-8

Zale, R. (1994). Changes in size of the Hope Bay Adélie penguin rookery as inferred from Lake Boeckella sediment. Ecography 17, 297-304. doi: 10.1111/j.16000587.1994.tb00106.x

Zheng, W., Xie, Z., and Bergquist, B. A. (2015). Mercury stable isotopes in ornithogenic deposits as tracers of historical cycling of mercury in Ross 
Sea, Antarctica. Environ. Sci. Technol. 49, 7623-7632. doi: 10.1021/acs.est.5b 00523

Conflict of Interest: The authors declare that the research was conducted in the absence of any commercial or financial relationships that could be construed as a potential conflict of interest.

Publisher's Note: All claims expressed in this article are solely those of the authors and do not necessarily represent those of their affiliated organizations, or those of the publisher, the editors and the reviewers. Any product that may be evaluated in this article, or claim that may be made by its manufacturer, is not guaranteed or endorsed by the publisher.

Copyright (c) 2021 Duda, Hargan, Michelutti, Blais, Grooms, Gilchrist, Mallory, Robertson and Smol. This is an open-access article distributed under the terms of the Creative Commons Attribution License (CC BY). The use, distribution or reproduction in other forums is permitted, provided the original author(s) and the copyright owner(s) are credited and that the original publication in this journal is cited, in accordance with accepted academic practice. No use, distribution or reproduction is permitted which does not comply with these terms. 